\title{
X-Ray Photoelectron Spectroscopy of Negative Electrodes from High-Power Lithium-Ion Cells Showing Various Levels of Power Fade
}

\author{
M. Herstedt ${ }^{a}$, D.P. Abraham ${ }^{b *}$ J.B. Kerr ${ }^{\mathrm{c}}$ K. Edström ${ }^{\mathrm{a}}$ \\ ångström Advanced Battery Centre, Department of Materials Chemistry, Ångström Laboratory, \\ Uppsala University, Box 538, S-751 21 Uppsala, Sweden. \\ ${ }^{b}$ Chemical Technology Division, Argonne National Laboratory, 9700 South Cass Ave., Argonne \\ 60439, USA. \\ ${ }^{c}$ Lawrence Berkeley National Laboratory, MS 62-203, 1 Cyclotron Road \\ Berkeley, CA 94720, USA.
}

\begin{abstract}
High-power lithium-ion cells for transportation applications are being developed and studied at Argonne National Laboratory. The current generation of cells containing $\mathrm{LiNi}_{0.8} \mathrm{Co}_{0.15} \mathrm{Al}_{0.05} \mathrm{O}_{2}$ based cathodes, graphite-based anodes, and $\mathrm{LiPF}_{6}$-based electrolytes show loss of capacity and power during accelerated testing at elevated temperatures. Negative electrode samples harvested from some cells that showed varying degrees of power and capacity fade were examined by Xray photoelectron spectroscopy (XPS). The samples exhibited a surface film on the graphite, which was thicker on samples from cells that showed higher fade. Furthermore, solvent-based compounds were dominant on samples from low power fade cells, whereas $\mathrm{LiPF}_{6}$-based products were dominant on samples from high power fade cells. The effect of sample rinsing and air exposure is discussed. Mechanisms are proposed to explain the formation of compounds suggested by the XPS data.
\end{abstract}

*Corresponding author: abraham@cmt.anl.gov 


\section{Introduction}

The capacity loss during the first few cycles of a Li-ion cell is believed to result from lithium consumption by reaction with electrolyte components leading to the formation of a Solid Electrolyte Interphase (SEI) [1, 2]. Because carbon-based electrodes are thermodynamically unstable in all known electrolytes during lithium ion intercalation this SEI layer plays the important role of protecting the graphite surfaces [3]. In addition to low electrolyte solubility and good adhesion to the graphite surface, the SEI layer should ideally have high lithium-ion conductivity to minimize overpotentials due to polarization, and negligible electronic conductivity to prevent further lithium consumption [4]. The composition and properties of the SEI layer depend on electrolyte components, type of anode material, electrochemical treatment and temperature [2, 5-9]. Ethylene Carbonate (EC) is commonly used in the electrolyte because of its excellent ability to form a stable SEI layer at the anode surface upon reduction [10, 11]. In contrast, lithium-ion intercalation is not possible in single-solvent propylene carbonate (PC) solutions containing $\mathrm{LiPF}_{6}$ apparently because of the inability to form stable SEI films [11-13].

The composition and nature of the SEI layer formed on lithium metal and carbonaceous materials, such as graphite and hard carbons, are still the subject of much controversy, even after two decades of research [5-7, 14-21]. Takeuchi et al. [19] studied dialkyl carbonate reduction on the anodes of a $\mathrm{LiCoO}_{2}$-petroleum coke lithium-ion cell and proposed pathways for the formation of hydrocarbons, lithium alkyl carbonates $\left(\mathrm{R}-\mathrm{OCO} \mathrm{CO}_{2}-\mathrm{Li}\right)$, lithium carbonate $\left(\mathrm{Li}_{2} \mathrm{CO}_{3}\right)$, lithium alkoxide (R-O-Li), and lithium hydroxide, which are the compounds usually reported to be present in the anode SEI layers. After extensive work by Fourier Transform Infrared (FTIR) spectroscopy and X-ray photoelectron spectroscopy (XPS) on graphite anodes from lab-scale cells, Aurbach and co-workers [7] concluded that lithium alkyl carbonates $\left(\mathrm{R}-\mathrm{OCO}_{2}-\mathrm{Li}\right)$, and possibly also lithium carbonate $\left(\mathrm{Li}_{2} \mathrm{CO}_{3}\right)$, are the main reduction products for the most commonly used solvents, ethylene carbonate (EC) and dimethyl carbonate (DMC). However, these compounds were not observed on graphite anodes harvested from 18650-cells [20]. Lithium alkyl carbonates and lithium carbonate were also not observed in the FTIR-Attenuated Total Reflection (ATR) study of graphite anodes by Zhuang and Ross [21], who concluded that the SEI layer was heterogeneous and contained lithium oxalate $\left(\mathrm{Li}_{2} \mathrm{C}_{2} \mathrm{O}_{4}\right)$, lithium carboxylates 
(RCOOLi) and lithium methoxide $\left(\mathrm{LiOCH}_{3}\right)$. Lithium hydroxide $(\mathrm{LiOH})$, methanol $\left(\mathrm{CH}_{3} \mathrm{OH}\right)$ and, in some cases, lithium hydrogen carbonate $\left(\mathrm{LiHCO}_{3}\right)$ were also reported for samples from cells subjected to accelerated aging [21].

An understanding of the SEI layer is a crucial part of deciphering the mechanisms that govern the capacity and power fade behavior of high-power lithium-ion cells being studied for hybrid electric vehicle applications as part of the U.S. Department of Energy's Advanced Technology Development (ATD) program [22-24]. Lithium ion-cells, ranging in capacity from $1 \mathrm{mAh}$ to $1 \mathrm{Ah}$, are being built and tested to determine suitable electrode-electrolyte combinations that will meet the calendar life, safety and cost goals of the ATD program $[25,26]$. The cells display loss of capacity and power under accelerated testing conditions [27, 28]. Measurements conducted in reference electrode cells have indicated that a major part of the impedance rise can be attributed to the positive electrode [29]. Although the sources of this impedance rise have not yet been unequivocally identified, acid and base-catalyzed polymerization of EC is known to occur and may produce polymers that increase electrolyte viscosity particularly within the composite cathodes that contain nanoparticulate carbon blacks. Electrochemical reduction reactions at the negative electrode may, however, govern the formation of polymeric species and hence the impedance rises at the positive electrode [30]. Furthermore, electron and lithium-ion consumption in side reactions at the negative electrode that yield inactive lithium compounds such as lithium oxide, hydroxide and alkoxides may produce the capacity loss observed during cell aging $[29,31,32]$.

In this article, in an effort to elucidate some of the anodic reactions, we describe X-ray photoelectron spectroscopy (XPS) measurements conducted to determine SEI layer constituents on negative electrode samples from 18650-cells that showed varying degrees of capacity and power fade. The SEI layer thickness changes on aging were determined by controlled sputtering experiments. Data on the effect of sample exposure to air and sample rinsing are also presented. Mechanisms are proposed to explain the formation of compounds suggested by the XPS data.

\section{Experimental}


The anode (negative electrode) samples used in this study were obtained from $\sim 1$ Ah capacity cylindrically wound (18650-type) cells that were fabricated by Quallion, Inc. Cell chemistry is detailed in Table 1. The cells contained a $\mathrm{LiNi}_{0.8} \mathrm{Co}_{0.15} \mathrm{Al}_{0.05} \mathrm{O}_{2}$-based cathode, a Mag-10 graphite-based anode and an $\mathrm{LiPF}_{6}$-based electrolyte. After formation cycling, the cells were shipped to Argonne National Laboratory (ANL) and stored at $10^{\circ} \mathrm{C}$ before testing commenced. Characterization included $\mathrm{C} / 1$ and $\mathrm{C} / 25$ capacity measurements, $\mathrm{AC}$ impedance measurements and hybrid pulse power characterization (HPPC) tests, which provided initial data on the cells. Some cells were potentiostated at $3.72 \mathrm{~V}$ and stored in a $55^{\circ} \mathrm{C}$ oven to accelerate degradation mechanisms that produce capacity and power fade. Cell performance was monitored daily by the application of a single discharge pulse. Every four weeks, the cells were cooled to $25^{\circ} \mathrm{C}$ and cycled from $3 \mathrm{~V}(0 \% \mathrm{SOC})$ to $4.1 \mathrm{~V}(100 \% \mathrm{SOC})$ to determine $\mathrm{C} / 1$ and $\mathrm{C} / 25$ capacity. Impedance measurements were also conducted to determine the effect of temperature on cell pulse-power performance characteristics [27].

The 18650-cells were taken off test after completing predetermined end-of-test criteria based on power fade [27]. Cell disassembly was conducted in an argon glovebox $\left(<1 \mathrm{ppm} \mathrm{H}_{2} \mathrm{O},<5 \mathrm{ppm}_{2}\right)$ and components stored in a sealed mason jar for diagnostic examination. The anode samples were obtained from cells that showed varying levels of capacity and power fade (see Table 2). One cell that was formed but not aged at $55^{\circ} \mathrm{C}$ had, by definition, $0 \%$ capacity and $0 \%$ power fade $(\mathrm{PF})$. The $15 \% \mathrm{PF}$ cell was characterized (by the suite of capacity and impedance measurements) twice, before and after the 4 week, $55^{\circ} \mathrm{C}$ aging. The $35 \%$ $\mathrm{PF}$ cell was characterized 11 ten times, before and during the course of the 40 week, $55^{\circ} \mathrm{C}$ aging.

Micrographs of the unrinsed (i.e., as-disassembled) anode samples were obtained with a Hitachi S-4700 scanning electron microscope (SEM) operating at $20 \mathrm{KeV}$; these samples saw brief $(<1$ min) air exposure during loading into the microscope.

Electrode surfaces were examined by XPS. The electrode pieces were mounted on the XPS

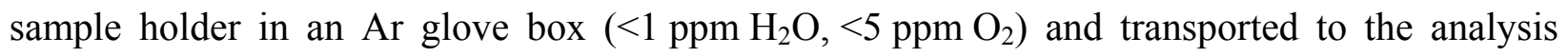
chamber under an Ar-atmosphere to avoid air-exposure. The XPS measurements were conducted on a PHI 5500 instrument using monochromatised $\mathrm{AlK}_{\alpha}$ radiation (at $1486.6 \mathrm{eV}$ ) at a base 
pressure of $5 \times 10^{-10}$ Torr and a working pressure $<5 \times 10^{-9}$ Torr. High-resolution spectra of the $\mathrm{C} 1 \mathrm{~s}, \mathrm{O} 1 \mathrm{~s}, \mathrm{~F} 1 \mathrm{~s}, \mathrm{P} 2 \mathrm{p}$ and Li1s regions were obtained with a pass-energy of $23.5 \mathrm{eV}$. Depth profiling was obtained by $\mathrm{Ar}^{+}$ion sputtering $(3 \mathrm{kV})$ during which the base pressure increased to $\sim 1 \times 10^{-9}$ Torr. The sample currents monitored during depth-profiling were similar, which suggested that the sputtering rates were similar for the samples examined.

XPS experiments were conducted on unrinsed anode samples, samples rinsed in DEC, and samples that were intentionally exposed to air for a $3 \mathrm{~h}$ period. The DEC rinse (conducted in a glove box) was used to remove electrolyte salt residues that are not inherent to the SEI. During rinsing, the electrode samples were soaked in $2 \mathrm{ml} \mathrm{DEC} \mathrm{for} 30 \mathrm{~min}$ and then dried for $1 \mathrm{~h}$ (under reduced pressure) at ambient temperature. Baseline data for the anodes was obtained by studying a fresh sample. Reference data for polyethylene oxide (PEO) (BDH Chemicals Ltd., England, and $\mathrm{MW} \sim 4 \times 10^{6}$ ) was obtained from a fresh anode that was spin-coated with PEO from an acetonitrile solution.

The binding energy scales for the high resolution spectra were calibrated with the graphite peak set to $284.5 \mathrm{eV}$. When the graphite peak was not observed, the sample spectra were calibrated with the main $\mathrm{C} 1 \mathrm{~s}$ peak set to $285.9 \mathrm{eV}$, which was the binding energy determined for the main $\mathrm{C} 1 \mathrm{~s}$ peak in spectra containing graphite. Peak assignments were made based on detailed curve fitting of the recorded spectra using Gaussian-Lorenzian peak shapes and a linear background correction, together with reference measurements. Element concentrations were calculated using integrated peak intensities and atomic sensitivity factors from the PHI instrumentation software [33].

\section{Results and Discussion}

\subsection{Scanning Electron Microscopy}

A typical SEM image obtained from the fresh laminate (see Fig. 1) showed the characteristic plate-like particles of Mag-10 graphite that are $\sim 5$ to $10 \mu \mathrm{m}$ wide with well-defined active edges; portions of the graphite that flaked off the surface are visible in the figure. Micrographs of the $0 \%$ power fade sample (Fig. 2a) were similar to those from the fresh laminate except for 
electrolyte residue that was occasionally visible on the particles; the PVdF binder was apparent in some micrographs. Micrographs of samples from high power fade cells (for example, Fig. 2b) showed a distinct rounding of the graphite edges. The surface flakes apparent in the fresh laminate were indistinct in these samples suggesting the presence of a layer that covered both the graphite surface and edges; the PVdF binder was not observed in micrographs from the high power fade cells.

\subsection{Surface analysis by XPS - Effect of aging}

\subsubsection{C1s spectra}

Typical spectra from a fresh anode laminate showed a graphite (C-C) peak, and C-H and C-F peaks from the PVdF binder (see Fig. 3a). In the $0 \%$ power fade $(\mathrm{PF})$ sample, the $\mathrm{C}-\mathrm{C}$ peak intensity was significantly lower; the peak intensity was higher in the rinsed sample, which indicated that the rinsing had successfully removed the electrolyte residue. However, the C-C peak intensity of the rinsed sample is significantly lower than that of the fresh sample, which indicates the presence of a layer (SEI) on the rinsed sample surface. Curve fitting of the $0 \% \mathrm{PF}$ rinsed sample data showed that the main peaks in the spectra are at 284.5, 285.8, 287.3 and 290.9 eV (see Fig. 3a).

The spectra of the rinsed $0 \%, 15 \%$ and 35\% PF samples are shown in Fig. 3b. The $284.5 \mathrm{eV}$ (graphite) peak is clearly visible in the $0 \%$ PF sample only; this peak appears as a shoulder in the $15 \% \mathrm{PF}$ sample, and is absent in the 35\% PF sample, which clearly indicates that the SEI layer thickness is greater on the higher power fade sample. The strongest peaks in the higher PF samples are at $285.9 \mathrm{eV}$ (dominant) and at $287.8 \mathrm{eV}$. Some intensity is also observed in the 290-291 range, which suggests the presence of carbonates in the SEI.

\subsubsection{F1s spectra}

The F1s spectra from a fresh anode laminate showed C-F peaks from the PVdF binder (see Fig. 4a) at $687.8 \mathrm{eV}$. The $0 \% \mathrm{PF}$ sample shows two peaks: the $\sim 686 \mathrm{eV}$ peak arises from $\mathrm{LiF}$ in the surface film. The $\sim 688 \mathrm{eV}$ peak contains contributions from the C-F bond in the binder and $\mathrm{PF}_{\mathrm{y}}$ species possibly from both SEI compounds and electrolyte salt residues. As expected, rinsing reduced the intensity arising from the electrolyte salt residue. However, the significant intensity 
at $\sim 688 \mathrm{eV}$ remaining after rinsing indicated that $\mathrm{PF}_{\mathrm{y}}$ species are a part of the SEI layer because the C-F binder peaks cannot account for all the observed intensity. Rinsing also increased LiF peak intensity, apparently by washing off the residue covering the compound.

The F1s spectra from the rinsed $0 \%, 15 \%$ and $35 \%$ PF samples are shown in Fig. $4 \mathrm{~b}$. The LiF peak intensity shows an obvious increase with power fade, which probably results from the increased reactions of $\mathrm{LiPF}_{6}$ at the longer aging periods. Because of the thicker SEI layer, the $\sim 688 \mathrm{eV}$ peak in the higher power fade samples may arise only from the $\mathrm{PF}_{\mathrm{y}}$ species and not from the binder.

\subsubsection{O1s, Li1s and P2p spectra}

The O1s spectra from the unrinsed $0 \%, 15 \%$ and $35 \%$ PF, shown in Fig. 5a, indicated that the spectral intensity increases with power fade. The spectral intensity also showed a significant increase on rinsing (see Figs. 5b), especially for the $0 \%$ and 35\% PF sample, as a result of uncovering O-bearing species. The peak at $\sim 533 \mathrm{eV}$ is the most prominent peak in the $\mathrm{O} 1 \mathrm{~s}$ spectra from the highest PF sample (both prior to and after rinsing). Furthermore, it may be noted that $\mathrm{Li}_{2} \mathrm{CO}_{3}$ (expected at $531.5 \mathrm{eV}$ ), and species like $\mathrm{Li}_{2} \mathrm{O}$ and $\mathrm{LiOH}$ (expected $<530 \mathrm{eV}$ ) are not detected in the O1s spectra.

The P2p spectra from the unrinsed $0 \%, 15 \%$ and $35 \%$ PF, shown in Fig. $6 a$, indicated that the P$\mathrm{O}$ species $\left(\mathrm{P} 2 \mathrm{p}_{3 / 2} \sim 134.6 \mathrm{eV}\right.$ and $\left.\mathrm{P} 2 \mathrm{p}_{1 / 2} \sim 135.4 \mathrm{eV}\right)$ intensity increases with power fade. The spectral intensity also showed a significant change on rinsing (see Fig. 6b); the $\mathrm{PF}_{\mathrm{y}}$ species intensity $\left(\mathrm{P} 2 \mathrm{p}_{3 / 2} \sim 137.1 \mathrm{eV}\right.$ and $\left.\mathrm{P} 2 \mathrm{p}_{1 / 2} \sim 138 \mathrm{eV}\right)$ from the electrolyte salt residue decreased, whereas the $\mathrm{PF}_{y} \mathrm{O}_{z}$ species intensity increased on rinsing. The increase in the $\mathrm{PF}_{y} \mathrm{O}_{z}$ intensity corresponds with the observed increase in the O1s spectra on rinsing and could have resulted from the uncovering of this species.

The Lils spectra of the unrinsed samples (Fig. 7a) did not show a trend with power fade, probably because of the Li-bearing electrolyte residue on the sample. The rinsed samples, however, showed a clear trend, showing greater Li-intensities at high power fade (Fig. 7b). The position of the peak maximum is slightly shifted to lower binding energies for the $35 \% \mathrm{PF}$ 
sample. The Li1s spectra probably include contributions from species such as $\mathrm{LiF}, \mathrm{Li}_{\mathrm{x}} \mathrm{PF}_{\mathrm{y}}$, $\mathrm{Li}_{\mathrm{x}} \mathrm{PF}_{\mathrm{y}} \mathrm{O}_{\mathrm{z}}$, and Li-bearing organic compounds.

\subsection{Depth profiles using $\mathrm{Ar}^{+}$-ion sputtering - relative SEI layer thickness changes on aging}

Samples from the $0 \%$ and $35 \% \mathrm{PF}$ rinsed electrodes were sputtered by $\mathrm{Ar}^{+}$ions to estimate the relative thicknesses of the SEI layer. The C1s, O1s, F1s, P2p and Li1s spectra prior to and after 60-s sputtering are shown in Fig. 8. For the $0 \%$ PF electrode, the C1s peaks (Fig. 8a) arising from the SEI components are almost completely removed after $60 \mathrm{~s}$ sputtering. In contrast, for the $35 \%$ PF electrode, although a graphite peak (at $284.5 \mathrm{eV}$ ) is observed, the SEI component peaks are still clearly discernible (Fig. 8a). A similar trend is observed in the O1s spectra (Fig. $8 \mathrm{c}, \mathrm{d})$, where the decrease in peak intensities after sputtering is much more significant for the $0 \%$ PF than for the $35 \%$ PF electrode. These data indicate that a thicker SEI is present on the higher power fade sample. The simultaneous decreases in peak intensities for two C1s peaks (at $285.9 \mathrm{eV}$ and $287.8 \mathrm{eV}$ ) suggest that these peaks originate from the same compound. Furthermore, the $\mathrm{O} 1 \mathrm{~s}$ peak below $530 \mathrm{eV}$ that appears after sputtering of the $35 \% \mathrm{PF}$ sample may be attributed to the sputter-induced formation of $\mathrm{LiOH}$ or $\mathrm{Li}_{2} \mathrm{O}$ [34].

The F1s spectra (Fig. 8e,f) show a decrease in $\mathrm{PF}_{\mathrm{y}}$ peak $(\sim 688 \mathrm{eV})$ intensities and an increase in LiF peak $(\sim 686 \mathrm{eV})$ intensities after 60 s sputtering for both $0 \%$ and $35 \% \mathrm{PF}$ samples. The LiF increase may have resulted from the sputter-induced decomposition of compounds such as $\mathrm{Li}_{\mathrm{x}} \mathrm{PF}_{\mathrm{y}}$ and $\mathrm{Li}_{\mathrm{x}} \mathrm{PF}_{\mathrm{y}} \mathrm{O}_{\mathrm{z}}$. This hypothesis is consistent with the reduction in the P-F and P-O peak intensities seen in the P2p spectra of the 0\% PF sample (Fig. 8g,h). For the 35\% PF sample, however, the P-O peak intensity does not decrease after sputtering. Furthermore, for both samples, the P2p spectra peaks shift to lower binding energies after sputtering. This shift indicates the presence of new P-bonds (probably P-O or P-P) that may have formed by sputterinduced reactions. The changes in Li1s peak positions and intensities are small for both $0 \%$ and $35 \%$ PF samples (Fig. 8i,j), which indicates that the Li peak is not very sensitive to changes in the Li-atom environment. Taken together, the F1s, P2p and Li1s spectra indicate that the 35\% $\mathrm{PF}$ sample SEI is thicker and contains more inorganic compounds (such as $\mathrm{LiF}$ ) than the $0 \% \mathrm{PF}$ sample SEI. 
The evolution of element concentration during sputtering of the $0 \%$ and $35 \% \mathrm{PF}$ samples are shown in Fig. 9. Several differences are observed between the samples. First, for the $0 \% \mathrm{PF}$ sample the dominant element is $\mathrm{C}$, whereas it is $\mathrm{F}$ for the 35\% PF sample. This observation indicates, again, that the SEI layer is more salt-based for the higher PF electrode. Second, the changes in relative atomic concentration during sputtering also differ. The $\mathrm{C}$ content increases after only 20 s for the $0 \%$ PF sample, whereas it increases after 120 s for the $35 \%$ PF sample. Although similar initially, the $\mathrm{O}$ content decreases faster for the $0 \% \mathrm{PF}$ sample. Both the $\mathrm{C}$ and $\mathrm{O}$ data are indicative of a thicker SEI layer on the $35 \% \mathrm{PF}$ sample. For both samples, the $\mathrm{F}$ content increases initially on sputtering and then decreases, which suggests that more F-bearing are exposed after initial sputtering. A similar trend on sputtering is observed for the Li content even though the relative concentration is higher for the $35 \%$ sample. The P contents do not change much on sputtering, which indicates that although the P-containing species decompose they are not removed by sputtering.

\subsection{Effect of air exposure on the SEI layer}

XPS analysis was attempted on electrodes that were exposed to air for $\sim 3$ minutes. These samples, however, degassed extensively and produced rapidly changing spectra, which indicated reactions in the SEI layer. Spectra obtained on samples after $3.5 \mathrm{~h}$ of air exposure were stable indicating that the SEI reactions were complete.

The effect of a $3.5 \mathrm{~h}$ air exposure on the SEI layers of the unrinsed $0 \%$ and $35 \% \mathrm{PF}$ samples is shown in Figs. 10a-g. The graphite peak shows a significant increase for the $0 \%$ PF sample, which indicates that some compound(s) in the original SEI layer reacted to form volatile species that were subsequently removed in the UHV chamber of the XPS instrument. The minor changes in intensities for the C1s peaks at $\sim 285.8, \sim 287.3$ and $\sim 290.9 \mathrm{eV}$, strongly indicate that these species are not particular sensitive to air or moisture. The O1s peak intensities were significantly greater for both air-exposed samples. The peaks also shifted to lower binding energies, which is consistent with the formation of $\mathrm{Li}_{2} \mathrm{CO}_{3}$ in the SEI layer [35].

The F1s spectra showed small changes after air exposure. The most prominent change in the P2p spectra is the increased intensity of the peak at $\sim 135.5 \mathrm{eV}\left(\mathrm{PF}_{\mathrm{y}} \mathrm{O}_{\mathrm{x}}\right.$ type compounds) for the $0 \%$ 
PF electrode after air exposure. The intensity of the peak at $\sim 135.5 \mathrm{eV}$ changes only minor for the $35 \% \mathrm{PF}$ electrode after air exposure. This is attributed to the fact that the $35 \% \mathrm{PF}$ electrode contains relatively large amounts of $\mathrm{PF}_{\mathrm{y}} \mathrm{O}_{\mathrm{x}}$ type compounds prior to air exposure. The Li1s spectra showed small changes after air exposure.

The following general conclusions may be drawn from the evolution of the spectra after air exposure. First, SEI compound(s) react with air or moisture to form volatile species that are removed before the analysis. Second, the effect on SEI composition was greater for the $0 \% \mathrm{PF}$ sample, a large increase in the amount of PO compound(s) was observed. And finally, the amount of carbon bearing compounds on these electrodes did not decrease by air exposure.

\section{Discussion}

Wang et al. studied EC reductive decomposition mechanisms in lithium-ion cell electrolyte solutions using density functional theory [36]. Their calculations showed that, thermodynamically, lithium butylene carbonate $\left(\mathrm{CH}_{2} \mathrm{CH}_{2} \mathrm{OCO}_{2} \mathrm{Li}\right)_{2}$ is the most likely product of $\mathrm{EC}$ reduction followed by an O-Li compound with an ester group, $\mathrm{LiO}\left(\mathrm{CH}_{2}\right)_{2} \mathrm{CO}_{2}\left(\mathrm{CH}_{2}\right)_{2} \mathrm{OCO}_{2} \mathrm{Li}$. Reaction pathways that lead to the formation of lithium ethylene dicarbonate $\left(\mathrm{CH}_{2} \mathrm{OCO}_{2} \mathrm{Li}\right)_{2}$ and ethylene gas $\left(\mathrm{C}_{2} \mathrm{H}_{4}\right)$, and a nucleophilic carbonate anion $\left(\mathrm{LiCO}_{3}{ }^{-}\right)$that can react with $\mathrm{Li}$ to form $\mathrm{Li}_{2} \mathrm{CO}_{3}$ were also considered likely.

Because of its high solubility in the electrolyte $\left(\mathrm{CH}_{2} \mathrm{CH}_{2} \mathrm{OCO}_{2} \mathrm{Li}\right)_{2}$ is not expected to be a dominant species in the SEI film [36] which is consistent with our data because the adjacent $\mathrm{CH}_{2}$ - linkages in the compound would have produced strong intensities at $285 \mathrm{eV}$ in our $\mathrm{C} 1 \mathrm{~s}$ data. Aurbach et al. have indicated that the dominant species in the anode SEI are usually lithiumalkyl carbonates, $\left(\mathrm{RCH}_{2} \mathrm{OCO}_{2} \mathrm{Li}\right)_{2}$, which produce 2 equal area peaks at $\sim 288 \mathrm{eV}$ and $\sim 290-291$ $\mathrm{eV}$ in the $\mathrm{C} 1 \mathrm{~s}$ spectra. The $\left(\mathrm{CH}_{2} \mathrm{OCO}_{2} \mathrm{Li}\right)_{2}$ compound was found in the SEI of anodes tested in various electrolytes. However, this compound was not observed on graphite anodes harvested from 18650-cells; the experimenters speculated that $\mathrm{HF}$ impurities in $\mathrm{LiPF}_{6}$-electrolytes react with the $\mathrm{ROCO}_{2} \mathrm{Li}$ and $\mathrm{Li}_{2} \mathrm{CO}_{3}$ to produce $\mathrm{LiF}$. Our C1s data is consistent with the absence of $\left(\mathrm{CH}_{2} \mathrm{OCO}_{2} \mathrm{Li}\right)_{2}$ in the anode SEI. 
Ross et al. postulated $\mathrm{Li}$-succinate $\left(\mathrm{LiOC}(=\mathrm{O}) \mathrm{CH}_{2} \mathrm{CH}_{2}(\mathrm{O}=) \mathrm{COLi}\right)$ as a model compound for Licarboxylates such as Li-formate, -acetate and -propionate that were observed as the dominant species in the SEI of anodes from aged 18650-cells [21]. Capillary electrophoresis analyses of extracts from our graphite anodes do not show the presence of lithium succinate [37]. However, several unknown peaks were observed in the electropherogram, which may arise from alkylcarboxylate compounds related to succinate [37]. These carboxylates may form by EC reduction followed by reaction with $\mathrm{CO}_{2}$ as shown in Fig. 11. Such compounds may be responsible for the intensities observed in our $\mathrm{C} 1 \mathrm{~s}$ data. For instance, the carbon atom adjacent to the ester carbon atom $\mathrm{C}(=\mathrm{O}) \underline{\mathrm{CH}_{2}} \mathrm{CH}_{3}$ is expected at $\sim 285.7 \mathrm{eV}$ [38]. The alkoxide carbon $\underline{\mathrm{C}} \mathrm{H}_{2} \mathrm{O}$ would appear at $\sim 287.5 \mathrm{eV}$, and the carboxylate carbon $\mathrm{OC}(=\mathrm{O}) \mathrm{R}$ is known to produce a peak at $288.3 \mathrm{eV}$ [29]. The O1s peaks for these compounds are expected at $\sim 532-533 \mathrm{eV}$, which are within the bounds of our O1s spectra. The alkoxide end of compound B in Fig. $11\left(\mathrm{O}(\mathrm{C}=\mathrm{O}) \mathrm{CH}_{2} \mathrm{CH}_{2} \mathrm{O}^{-}\right)$could react further with $\mathrm{EC}, \mathrm{EMC}$ or $\mathrm{PF}_{5}$ to form organophosphorous compounds.

Reduction of EMC can result in Li-carboxylates $(\mathrm{R}(\mathrm{C}=\mathrm{O}) \mathrm{OLi})$ together with Li-alkoxides (ROLi). The reactions may be schematically depicted as follows:

$\mathrm{CH}_{3} \mathrm{CH}_{2} \mathrm{O}(\mathrm{C}=\mathrm{O}) \mathrm{OCH}_{3} \stackrel{+e^{-}}{\longrightarrow} \mathrm{CH}_{3} \mathrm{CH}_{2} \mathrm{O}\left(\mathrm{C}^{\bullet}-\mathrm{O}^{-}\right) \mathrm{OCH}_{3}$

$\mathrm{CH}_{3} \mathrm{CH}_{2} \mathrm{O}\left(\mathrm{C}^{\bullet}-\mathrm{O}^{-}\right) \mathrm{OCH}_{3} \stackrel{+2 \mathrm{Li}^{+}+e^{-}}{\rightarrow} \mathrm{LiO}(\mathrm{C}=\mathrm{O}) \mathrm{CH}_{3}+\mathrm{CH}_{3} \mathrm{CH}_{2} \mathrm{OLi}$

$\mathrm{CH}_{3} \mathrm{CH}_{2} \mathrm{O}\left(\mathrm{C}^{\bullet}-\mathrm{O}^{-}\right) \mathrm{OCH}_{3} \stackrel{+2 i^{+}+e^{-}}{\rightarrow} \mathrm{LiO}(\mathrm{C}=\mathrm{O}) \mathrm{CH}_{3} \mathrm{CH}_{2}+\mathrm{CH}_{3} \mathrm{OLi}$

The presence of small quantities of lithium methoxide $\left(\mathrm{LiOCH}_{3}\right)$ in the anode SEI was reported by Ross et al. [21]. These Li-alkoxides would appear at $287.5 \mathrm{eV}$ in our C1s spectra [16], and at $\sim 532.3 \mathrm{eV}$ in the O1s spectra, which both overlap the Li-carboxylate regions. Li-alkoxides are known to react rapidly with water to form the corresponding alcohols, which would volatilize off under the UHV conditions of the XPS chamber. The persistence of the $\sim 287.5 \mathrm{eV}$ peak in our $\mathrm{C} 1 \mathrm{~s}$ spectra after air exposure indicates that Li-alkoxides, if present, are only a minor component of the SEI layer. 
The intensity at $\sim 290-291 \mathrm{eV}$ suggests the presence of carbonates in the SEI layer. Some of this intensity may be from carbonate-bearing compounds (such as A in Fig. 11). Carbonate compounds also result from the following transesterification reactions during initial cell cycling:

$$
2 \mathrm{EMC} \leftrightarrow \mathrm{DMC}+\mathrm{DEC}
$$

These linear carbonates react further with $\mathrm{EC}$ to form DMDOHC (reaction 8), EMDOHC (reaction 9), and DEDOHC (reaction 10):

$\mathrm{CH}_{2} \mathrm{CH}_{2} \mathrm{OCO}_{2}+\mathrm{CH}_{3} \mathrm{OCO}_{2} \mathrm{CH}_{3} \leftrightarrow \mathrm{CH}_{3} \mathrm{OCO}_{2} \mathrm{CH}_{2} \mathrm{CH}_{2} \mathrm{O}_{2} \mathrm{COCH}_{3}$

$\mathrm{CH}_{2} \mathrm{CH}_{2} \mathrm{OCO}_{2}+\mathrm{CH}_{3} \mathrm{CH}_{2} \mathrm{OCO}_{2} \mathrm{CH}_{3} \leftrightarrow \mathrm{CH}_{3} \mathrm{CH}_{2} \mathrm{OCO}_{2} \mathrm{CH}_{2} \mathrm{CH}_{2} \mathrm{O}_{2} \mathrm{COCH}_{3}$

$\mathrm{CH}_{2} \mathrm{CH}_{2} \mathrm{OCO}_{2}+\mathrm{CH}_{3} \mathrm{CH}_{2} \mathrm{OCO}_{2} \mathrm{CH}_{2} \mathrm{CH}_{3} \leftrightarrow \mathrm{CH}_{3} \mathrm{CH}_{2} \mathrm{OCO}_{2} \mathrm{CH}_{2} \mathrm{CH}_{2} \mathrm{O}_{2} \mathrm{COCH}_{2} \mathrm{CH}_{3}$

These transesterification products have been observed in $\mathrm{LiPF}_{6}$-electrolytes upon heating by gas chromatography [30] and high-performance liquid chromatography [17, 29]. The reactions have been suggested to be activated by alkoxide anions $\left(\mathrm{RO}^{-}\right)$at the negative electrode $[17,19]$.

The observed carbonate peak may also contain contributions from polyethercarbonates, which are known to form from the acid $\left(\mathrm{PF}_{5}\right)$-catalyzed ring-opening of $\mathrm{EC}$ molecules $[5,39,40]$. In addition, polyethercarbonates may form from base-catalyzed ring-opening of EC molecules by alkoxide anions $\left(\mathrm{RO}^{-}\right)$at the negative electrode. The evolution of $\mathrm{CO}_{2}$ from the ethercarbonates produces PEO-like polymers, which may be expected in the anode SEI layer. A reference measurement of PEO spin-coated on our anodes shows a C1s peak at $286.5 \mathrm{eV}$ and an $\mathrm{O} 1 \mathrm{~s}$ peak at $533.0 \mathrm{eV}$. In the 18650-cell anode data, a distinct peak is not observed at $286.5 \mathrm{eV}$ (Fig.3, for example), which suggests that that PEO (if present) is not the dominant species in the SEI layer. The PEO-like polymers produced from the ethercarbonates could have reacted with $\mathrm{PF}_{5}$ [31] to form organic-fluorinated and organofluoro-phosphorous compounds that have been reported by Aurbach et al. [20]. It has been noted by GC analysis that polyethylene glycol dimethylether 250 undergoes reactions upon addition of $\mathrm{LiPF}_{6}$ that lead to chain cleavage and chain growth. Similarly diethylene glycoldibutyl ether reacts when added to $\mathrm{LiPF}_{6}$-containing electrolytes. These observations indicate that any ether compounds formed will react further with $\mathrm{PF}_{5}$ [41] to possibly yield phosphorus-containing organic compounds, including higher molecular weight species. 
Aurbach has indicated that $\mathrm{Li}_{2} \mathrm{CO}_{3}$ is an important constituent of the anode SEI, especially at low EC concentrations [7]. However, $\mathrm{Li}_{2} \mathrm{CO}_{3}$ was not observed on anodes from aged 18650-cells. The absence of $\mathrm{Li}_{2} \mathrm{CO}_{3}$ on graphite anodes from 18650-cells was also reported by Zhuang and Ross [21], which is consistent with our XPS data. Preliminary experiments [39] have shown that significant amounts of $\mathrm{CO}_{2}$ are produced when $\mathrm{Li}_{2} \mathrm{CO}_{3}$ is immersed in our electrolyte (EC:EMC $+\mathrm{LiPF}_{6}$ ). The $\mathrm{CO}_{2}$ may have resulted from the reaction with $\mathrm{HF}$, which is a contaminant in $\mathrm{LiPF}_{6}$-electrolytes, according to the following equation:

$$
\mathrm{Li}_{2} \mathrm{CO}_{3}+\mathrm{HF} \leftrightarrow \mathrm{LiF}+\mathrm{H}_{2} \mathrm{O}+\mathrm{CO}_{2}
$$

The $\mathrm{H}_{2} \mathrm{O}$ generated from this reaction may explain the hydrolysis of lithium methoxide $\left(\mathrm{CH}_{3} \mathrm{OLi}\right)$ reported by Zhuang and Ross [21]. Alternatively, a reaction involving $\mathrm{PF}_{5}$ and $\mathrm{Li}_{2} \mathrm{CO}_{3}$ may account for the observed $\mathrm{CO}_{2}$ evolution together with formation of $\mathrm{P}-\mathrm{O}$ type compound and $\mathrm{LiF}$. No HF is required to rationalize the observation. Furthermore water, which is known to be detrimental for lithium-ion cells, would not be produced during the reaction.

The F1s, Li1s and $\mathrm{P} 2 \mathrm{p}$ spectra indicate the presence of $\mathrm{LiF}, \mathrm{Li}_{\mathrm{x}} \mathrm{PF}_{\mathrm{y}}$ and $\mathrm{Li}_{\mathrm{x}} \mathrm{PF}_{\mathrm{y}} \mathrm{O}_{\mathrm{z}}$ compounds in the SEI layer. The $\mathrm{LiF}$ and $\mathrm{Li}_{\mathrm{x}} \mathrm{PF}_{\mathrm{y}}$ compounds may be produced from the following $\mathrm{LiPF}_{6}$ decomposition and electrochemical reduction reactions:

$$
\mathrm{LiPF}_{6} \leftrightarrow \mathrm{LiF}+\mathrm{PF}_{5}
$$

The $\mathrm{PF}_{5}$ can react with $\mathrm{Li}$-ions to form $\mathrm{Li}_{\mathrm{x}} \mathrm{PF}_{\mathrm{y}}$-compounds [42]. The $\mathrm{Li}_{\mathrm{x}} \mathrm{PF}_{\mathrm{y}} \mathrm{O}_{z}$ compounds could form from $\mathrm{LiPF}_{6}$ reactions with $\mathrm{H}_{2} \mathrm{O}$, such as the following equations [42]:

$$
\begin{aligned}
& \mathrm{LiPF}_{6}+\mathrm{H}_{2} \mathrm{O} \rightarrow \mathrm{LiF}+\mathrm{POF}_{3}+2 \mathrm{HF} \\
& \mathrm{POF}_{3}+2 \mathrm{xLi}+2 \mathrm{xe}^{-} \rightarrow \mathrm{xLiF}+\mathrm{Li}_{\mathrm{x}} \mathrm{PF}_{3-\mathrm{x}} \mathrm{O}
\end{aligned}
$$

Reactions 11 and 12 are possible during cell formation because of the small quantity of water in the starting electrolyte. However, the continuing presence of water in the aged cells remains a matter of debate. The increase in the $\mathrm{PF}_{\mathrm{y}} \mathrm{O}_{\mathrm{z}}$ species intensity on aging could be from $\mathrm{PF}_{5}$ reactions with the solvent that produce the organic-fluorinated and organofluoro-phosphorous compounds mentioned previously.

In high power fade samples, the $\mathrm{LiPF}_{6}$-reaction products replaced the solvent-reduction species as the dominant compounds in the SEI layer. The relative LiF content more than doubled from $\sim 22 \%$ in the $0 \% \mathrm{PF}$ electrode to $\sim 49 \%$ in the $35 \% \mathrm{PF}$ electrode. The increased $\mathrm{LiF}$ content 
apparently results from more $\mathrm{LiPF}_{6}$ reactions for the longer aging periods. The electronconsuming side-reactions may contribute to cell-capacity fade with aging. The $\mathrm{LiF}, \mathrm{Li}_{\mathrm{x}} \mathrm{PF}_{\mathrm{y}}$ and $\mathrm{Li}_{\mathrm{x}} \mathrm{PF}_{\mathrm{y}} \mathrm{O}_{\mathrm{z}}$ in the SEI can act as barriers to lithium-ion motion, which can increase electrode impedance and contribute to cell power fade.

\section{Conclusions}

X-ray photoelectron spectroscopy measurements show that the graphite-based negative electrodes from our 18650-cells are coated with a SEI layer, which has the following characteristics:

1. The relative thickness of the SEI layer is greater on samples from cells showing higher power fade.

2. The constitution of the SEI layer varies with cell aging. EC- and EMC-reduction products are dominant in the SEI layer of anodes harvested from low power-fade cells. $\mathrm{LiPF}_{6}$-reaction products are dominant in the SEI layer of anodes harvested from high power-fade cells.

3. Our data is consistent with the absence of lithium alkyl carbonates $\left(\mathrm{ROCO}_{2} \mathrm{Li}\right)$ and $\mathrm{Li}_{2} \mathrm{CO}_{3}$ in the SEI layer. The dominant solvent-reduction products appear to be a carboxylate-based compounds, such as lithium-formate, -acetate and -propionate.

4. The higher contents of $\mathrm{LiF}, \mathrm{Li}_{\mathrm{x}} \mathrm{PF}_{\mathrm{y}}$ and $\mathrm{Li}_{\mathrm{x}} \mathrm{PF}_{\mathrm{y}} \mathrm{O}_{\mathrm{z}}$ in the $\mathrm{SEI}$ of aged samples are consistent with the higher capacity and power fades exhibited by these cells.

5. Rinsing appears effective in removing electrolyte residue. The $\mathrm{Li}_{\mathrm{x}} \mathrm{PF}_{\mathrm{y}}$ and carbonate species observed after rinsing are inherent to the SEI layer.

6. Air exposure produces significant changes to the SEI layer, which underlines the importance of conducting the anode XPS studies without air or moisture exposure.

\section{Acknowledgments}

This work was supported by the U.S. Department of Energy, Office of Advanced Automotive Technologies, under contract No.W-31-109-ENG-38, The Swedish Science Council (VR) and the Göran Gustafsson Foundation. We are grateful for the help and support of R. Gerald, Y.-E. Hyung, D. Dees and G. Henriksen at National Laboratory. We also recognize the contributions

of S. MacLaren, R. Haasch and E. Sammann from the Center for Microanalysis of Materials at 
the University of Illinois at Urbana-Champaign; this facility is partially supported by the U.S. Department of Energy under grant DEFG02-91ER45439. 


\section{References}

[1] E. Peled, D. Golodnitsky, C. Menachem, D. Bar-Tow, J. Electrochem. Soc., 145 (1998) 3482.

[2] (a) Peled E., J Electrochem Soc, 126 (1979) 2047. (b) E. Peled, in J.O. Besenhard (Ed.). Handbook of Battery Materials, Wiley-VCH, Weinheim, 1999.

[3] M. Winter, J.O. Besenhard, M.E. Spahr, P. Novak, Advanced Materials, 10 (1998) 725.

[4] Y. Ein-Eli, Electrochem. Solid-State Lett., 2 (1999) 212.

[5] A.M. Andersson, K. Edstrom, J. Electrochem. Soc., 148 (2001) A1100.

[6] A.M. Andersson, M. Herstedt, A.G. Bishop, K. Edstrom, Electrochim. Acta, 47 (2002) 1885.

[7] D. Aurbach, B. Markovsky, I. Weissman, E. Levi, Y. Ein-Eli, Electrochim. Acta, 45 (1999)

67.

[8] J.S. Gnanaraj, M.D. Levi, Y. Gofer, D. Aurbach, M. Schmidt, J. Electrochem. Soc., 150 (2003) A445.

[9] D. Aurbach, H. Teller, E. Levi, J. Electrochem. Soc., 149 (2002) A1255.

[10] D. Aurbach, Y. Ein-Eli, B. Markovsky, A. Zaban, J. Electrochem. Soc., 142 (1995) 2882.

[11] R. Fong, U. von Sacken, J.R. Dahn, J. Electrochem. Soc., 137 (1990) 2009.

[12] M. Arakawa and J. Yamaki, J. Electroanal. Chem., 219 (1987) 273.

[13] M. Yoshio, H. Wang, K. Fukuda. Y. Hara, Y. Adachi, J. Electrochem. Soc., 147 (2000) 1245.

[14] D. Aurbach, M.L. Daroux, P.W. Faguy, E. Yeager, J. Electrochem. Soc., 134 (1987) 1611.

[15] G.R. Zhuang, Y.F. Chen, P.N. Ross, Jr., Langmuir 15 (1999) 1470.

[16] L.J. Rendek, Jr., G.S. Chottiner, D.A. Scherson, J. Electrochem. Soc., 149 (2002) E408.

[17] H. Yoshida, T. Fukunaga, T. Hazama, M. Terasaki, M. Mizutani, M. Yamachi, J. Power Sources, 68 (1997) 311.

[18] D. Aurbach, J. Power Sources, 89 (2000) 206.

[19] E.S. Takeuchi, H. Gan, M. Palazzo, R.A. Leising, S.M. Davis, J. Electrochem. Soc., 144 (1997) 1944.

[20] D. Aurbach, B. Markovsky, A. Rodkin, M. Cojocaru, E. Levi, H-J. Kim, Electrochim. Acta, 47 (2002) 1899.

[21] G.R. Zhuang, P.N. Ross, Jr., Electrochem. Solid-State Lett., 6 (2003) A136.

[22] C.H. Chen, J. Liu, K. Amine, J. Power Sources, 96 (2001) 321. 
[23] M. Balasubramanian, X. Sun, X.Q. Yang, J. McBreen, J. Electrochem. Soc., 147 (2000) 2903.

[24] X. Zhang, P.N. Ross, Jr., R. Kostecki, F. Kong, S. Sloop, J.B. Kerr, K. Striebel, E.J. Cairns, and F. McLarnon, J. Electrochem. Soc., 148 (2001) A463.

[25] J. Kim, K. Amine, J. Power Sources, 104 (2002) 33.

[26] S.-H. Kang, J. Kim, M.E. Stoll, D. Abraham, Y.K. Sun, K. Amine, J. Power Sources, 112 (2002) 41.

[27] I. Bloom, S.A. Jones, E.G. Polzin, V.S. Battaglia, G.L. Henriksen, C.G. Motlock, R.B. Wright, R.G. Jungst, H.L. Case, D.H. Doughty, J. Power Sources, 111 (2002) 152.

[28] B.G. Potter, S.A. Jones, G.L. Henriksen, C. Motloch, J. Christophersen, J. Belt, I. Bloom, Power Source Modelling Symp. Proc., 202 ${ }^{\text {nd }}$ Meeting of The Electrochemical Society, Salt Lake City, UT, October 20-24 (2002).

[29] D.P. Abraham, unpublished data, Argonne National Laboratory, (2004).

[30] S. E. Sloop, J. B. Kerr, K. Kinoshita, J. Power Sources, 119-121 (2003) 330.

[31] P. Arora, R. White, M. Doyle, J. Electrochem. Soc., 145 (1998) 3647.

[32] R. Spotnitz, J. Power Sources, 113 (2003) 72.

[33] C. Wagner, W. Riggs, L. Davis, J. Moulder and G. Muilenbery, Perkin-Elmer Corp., Physical Electronics Division, Eden Prairie MN, 1979.

[34] A.M. Andersson, A. Henningson, H. Siegbahn, U. Jansson, K. Edström, J. Power Sources, 119-121 (2003) 522.

[35] G.R. Zhuang, K. Wang, Y. Chen, P.N. Ross, Jr., J. Vac. Sci. Technol. A, 16 (1998) 3041.

[36] Y. Wang, S. Nakamura, M. Ue, P. B. Balbuena, J. Am. Chem. Soc., 123 (2001) 11708.

[37] J.B. Kerr, unpublished data, Lawrence Berkeley National Laboratory, (2004).

[38] G. Beamson and D. Briggs, High Resolution XPS of Organic Polymers, Wiley, Chichester, 1992.

[39] J.-C. Lee and M. Litt, Macromolecules, 33 (2000) 1618.

[40] L. Vogdanis and W. Heitz, Macromol. Chem., Rapid Commun., 7 (1986) 543.

[41] F.A. Cotton, G. Wilkinson, C.A. Murillo, M. Bochmann, Advanced Inorganic Chemistry, Wiley, New York, 1999.

[42] D. Aurbach, B. Markovsky, A. Schechter, Y. Ein-Eli, H. Cohen J. Electrochem. Soc., 143 (1996) 3809. 
Table 1. Components of the 18650-cells studied

\begin{tabular}{|l|l|}
\hline \multicolumn{2}{|l|}{ Negative Electrode } \\
\hline Coating composition & Mag-10 graphite $(91 \mathrm{wt} \%)+\mathrm{PVdF}$ binder $(9 \mathrm{wt} \%)$ \\
\hline Coating thickness & Double sided, $35 \mu \mathrm{m}$ per side \\
\hline Current Collector & $\mathrm{Cu}$ foil, $18 \mu \mathrm{m}$ thick \\
\hline Positive Electrode & \multicolumn{2}{|l|}{$\begin{array}{l}\text { Coating composition } \\
\text { LiNi }{ }_{0.8} \mathrm{Co}_{0.15} \mathrm{Al}_{0.05} \mathrm{O}_{2}(84 \mathrm{wt} \%)+\mathrm{SFG}-6 \text { graphite }(4 \mathrm{wt} \%)\end{array}$} \\
\hline Coating thickness & Double sided, $35 \mu \mathrm{m}$ per side \\
\hline Current Collector & Al foil, $30 \mu \mathrm{m}$ thick \\
\hline Electrolyte & EC:EMC $(3: 7 \mathrm{wt} \%)+1.2 \mathrm{M} \mathrm{LiPF} 6$ \\
\hline Separator & Celgard $2325,25 \mu \mathrm{m}$ thick \\
\hline
\end{tabular}


Table 2. Source of negative electrode samples studied by XPS

\begin{tabular}{|l|l|l|}
\hline Sample Description & $\mathbf{C F} \%^{\mathrm{a}}$ & $\mathbf{P F}^{\mathrm{b}}$ \\
\hline $\begin{array}{l}\text { Fresh electrode laminate, no electrolyte } \\
\text { contact }\end{array}$ & - & - \\
\hline Formed cell, no $55^{\circ} \mathrm{C}$ aging & 0 & 0 \\
\hline Cell aged 4 weeks at $55^{\circ} \mathrm{C}, 3.72 \mathrm{~V}$ & 3.7 & 15.4 \\
\hline Cell aged 40 weeks at $55^{\circ} \mathrm{C}, 3.72 \mathrm{~V}$ & 17.5 & 35 \\
\hline
\end{tabular}

${ }^{\mathrm{a}} \mathrm{C} / 1$ capacity fade, ${ }^{b}$ Power fade 


\section{LIST OF FIGURES}

1. Fig. 1. SEM image of Mag-10 graphite in the fresh laminate shows characteristic plate-like particles with well-defined edges.

2. Fig. 2. SEM images of Mag-10 graphite from (a) $0 \%$ power fade, and (b) $50 \%$ power fade sample.

Fig. 3. (a) C1s spectra from Fresh (no electrolyte contact), and $0 \% \mathrm{PF}$ samples as dissembled and after rinsing. (b) Comparing $\mathrm{C} 1 \mathrm{~s}$ spectra from rinsed $0 \%, 15 \%$ and $35 \% \mathrm{PF}$ samples.

Fig. 4. (a) F1s spectra from Fresh (no electrolyte contact), and $0 \% \mathrm{PF}$ samples as dissembled and after rinsing. (b) Comparing F1s spectra from rinsed $0 \%, 15 \%$ and $35 \%$ PF samples.

Fig. 5. (a) O1s spectra from as disassembled $0 \%, 15 \%$ and $35 \%$ PF samples. (b) Comparing F1s spectra from rinsed $0 \%, 15 \%$ and $35 \%$ PF samples. Spectra are shown on same intensity scale.

Fig. 6. (a) P2p spectra from as disassembled $0 \%, 15 \%$ and $35 \% \mathrm{PF}$ samples.

(b) Comparing P2p spectra from rinsed $0 \%, 15 \%$ and $35 \%$ PF samples. Spectra are shown on same intensity scale.

Fig. 7. (a) Li1s spectra from as disassembled $0 \%, 15 \%$ and $35 \%$ PF samples.

(b) Comparing Li1s spectra from rinsed $0 \%, 15 \%$ and $35 \%$ PF samples. Spectra are shown on same intensity scale.

Fig. 8. Spectra prior to and after 60 s sputtering. Spectra for the $0 \% \mathrm{PF}$ and $35 \% \mathrm{PF}$ electrode samples are shown on the same intensity scale for each element. (a) $\mathrm{C} 1 \mathrm{~s}, 0 \% \mathrm{PF}$ and (b) $\mathrm{C} 1 \mathrm{~s}$, $35 \% \mathrm{PF}$, (c) O1s, $0 \% \mathrm{PF}$ and (d) O1s, 35\% PF electrodes, (e) F1s, $0 \% \mathrm{PF}$ and (f) F1s, 35\% PF, (g) P2p, 0\% PF and (b) P2p, 35\% PF electrodes, (i) Li1s, 0\% PF and (j) Li1s, 35\% PF electrode. 
Fig. 9. Relative atomic concentration for (a) rinsed $0 \% \mathrm{PF}$ and (b) rinsed 35\% $\mathrm{PF}$ electrodes prior to and after sputtering for $20 \mathrm{~s}, 60 \mathrm{~s}, 120 \mathrm{~s}$, and $240 \mathrm{~s}$.

Fig. 10. Spectra after air exposure for $3.5 \mathrm{~h}$. Data for the $0 \% \mathrm{PF}$ and $35 \% \mathrm{PF}$ electrode samples are shown on the same intensity scale. (a) $\mathrm{C} 1 \mathrm{~s}, 0 \% \mathrm{PF}$ and (b) $\mathrm{C} 1 \mathrm{~s}, 35 \% \mathrm{PF}$, (c) $\mathrm{O} 1 \mathrm{~s}, 0 \% \mathrm{PF}$ and (d) O1s, 35\% PF electrodes, (e) F1s, 0\% PF and (f) F1s, 35\% PF, (g) P2p, 0\% PF and (b) P2p, 35\% PF electrodes, (i) Li1s, 0\% PF and (j) Li1s, 35\% PF electrode.

Fig. 11. Schematic showing the formation of alkyl-carboxylate (A) by EC reduction followed by reaction with $\mathrm{CO}_{2}$. An alkoxide (B) can result from the loss of $\mathrm{CO}_{2}$ from the carboxylate as shown. 
Fig. 1. SEM image of Mag-10 graphite in the fresh laminate shows characteristic plate-like particles with well-defined edges.

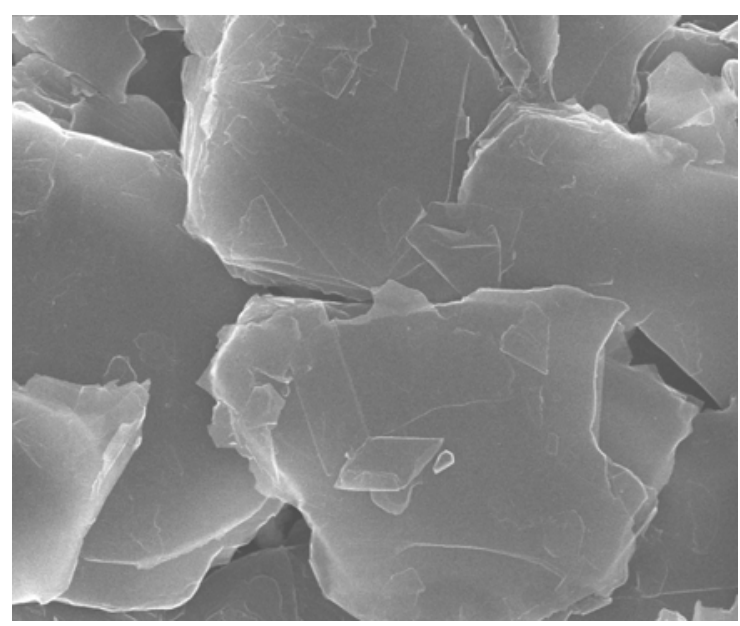


Fig. 2. SEM images of Mag-10 graphite from (a) 0\% power fade, and (b) 50\% power fade sample.

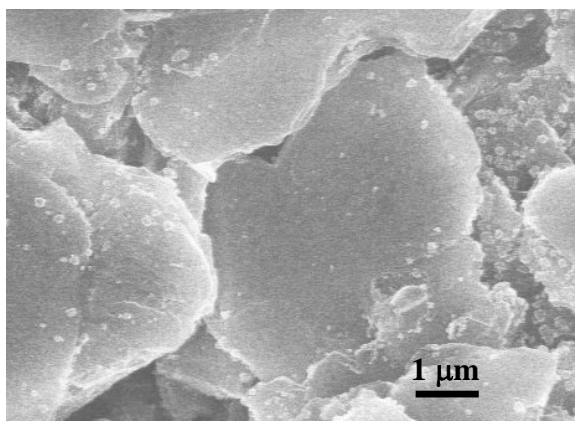

(a)

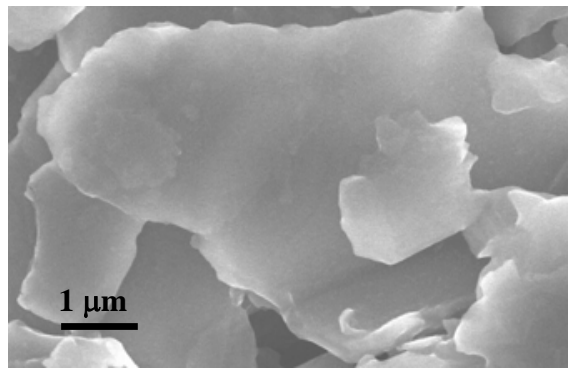

(b) 
Fig. 3. (a) C1s spectra from Fresh (no electrolyte contact), and 0\% PF samples as dissembled and after rinsing. (b) Comparing $\mathrm{C} 1$ s spectra from rinsed $0 \%, 15 \%$ and 35\% PF samples.
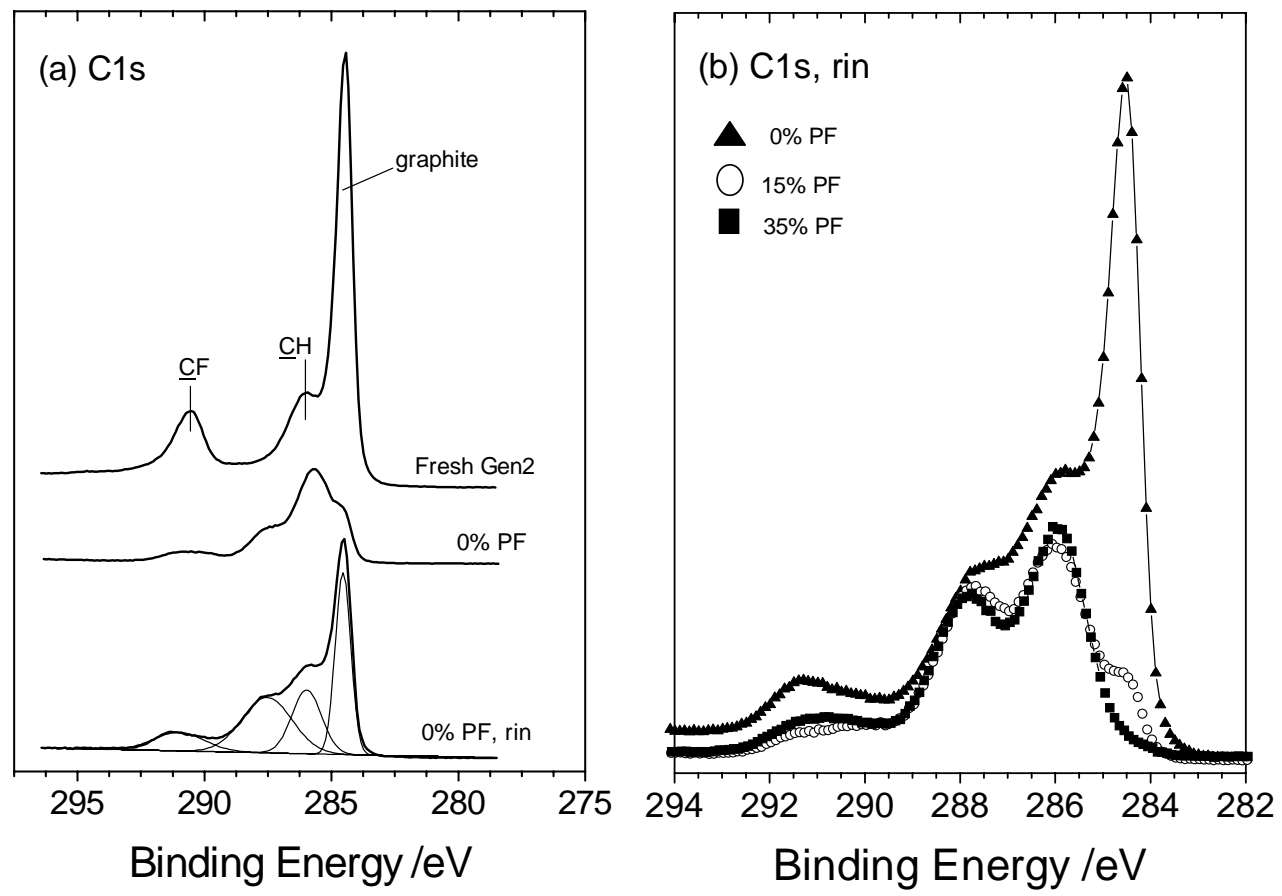
Fig. 4. (a) F1s spectra from Fresh (no electrolyte contact), and 0\% PF samples as dissembled and after rinsing. (b) Comparing F1s spectra from rinsed 0\%, 15\% and $35 \%$ PF samples.
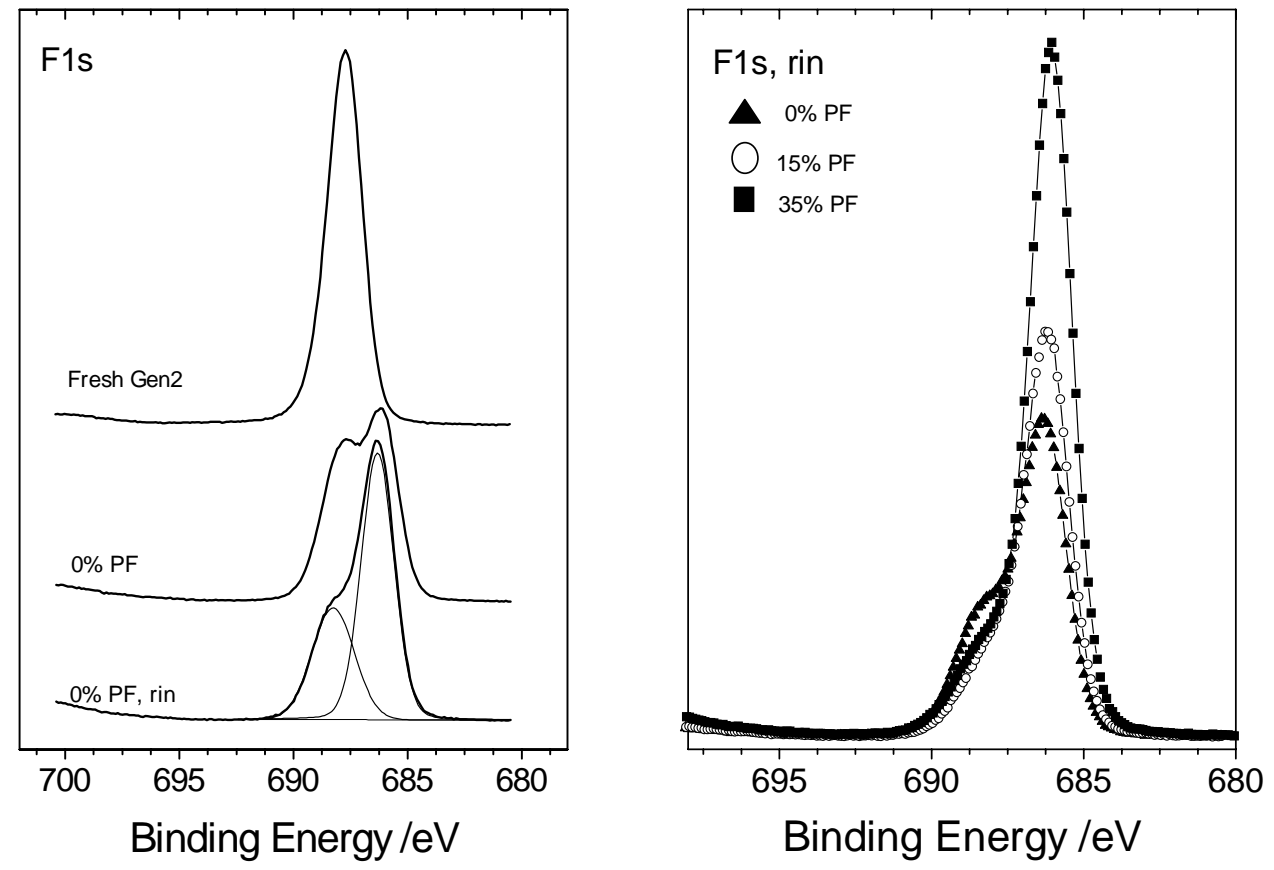
Fig. 5. (a) O1s spectra from as disassembled 0\%, 15\% and 35\% PF samples. (b) Comparing F1s spectra from rinsed 0\%, 15\% and 35\% PF samples. Spectra are shown on same intensity scale.
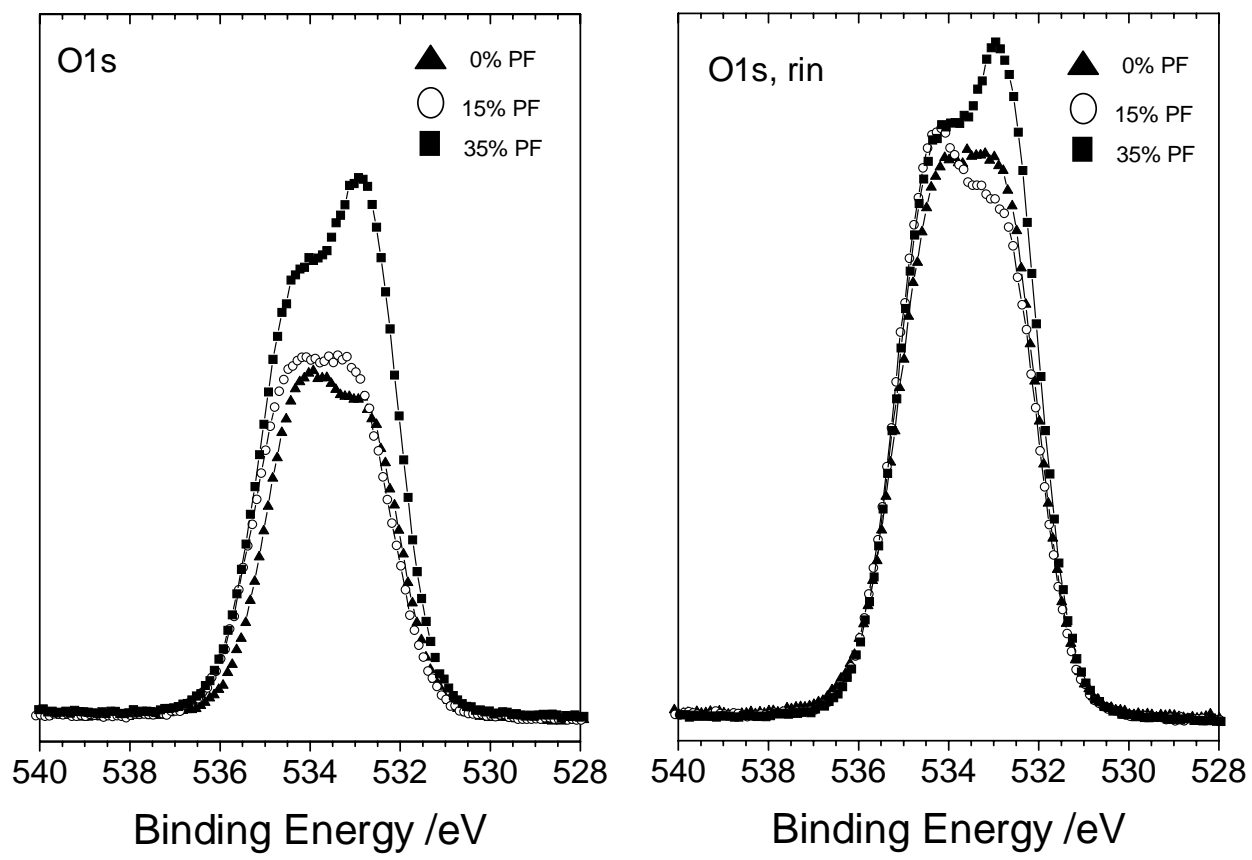
Fig. 6. (a) P2p spectra from as disassembled $0 \%, 15 \%$ and $35 \%$ PF samples.

(b) Comparing P2p spectra from rinsed 0\%, 15\% and 35\% PF samples. Spectra are shown on same intensity scale.
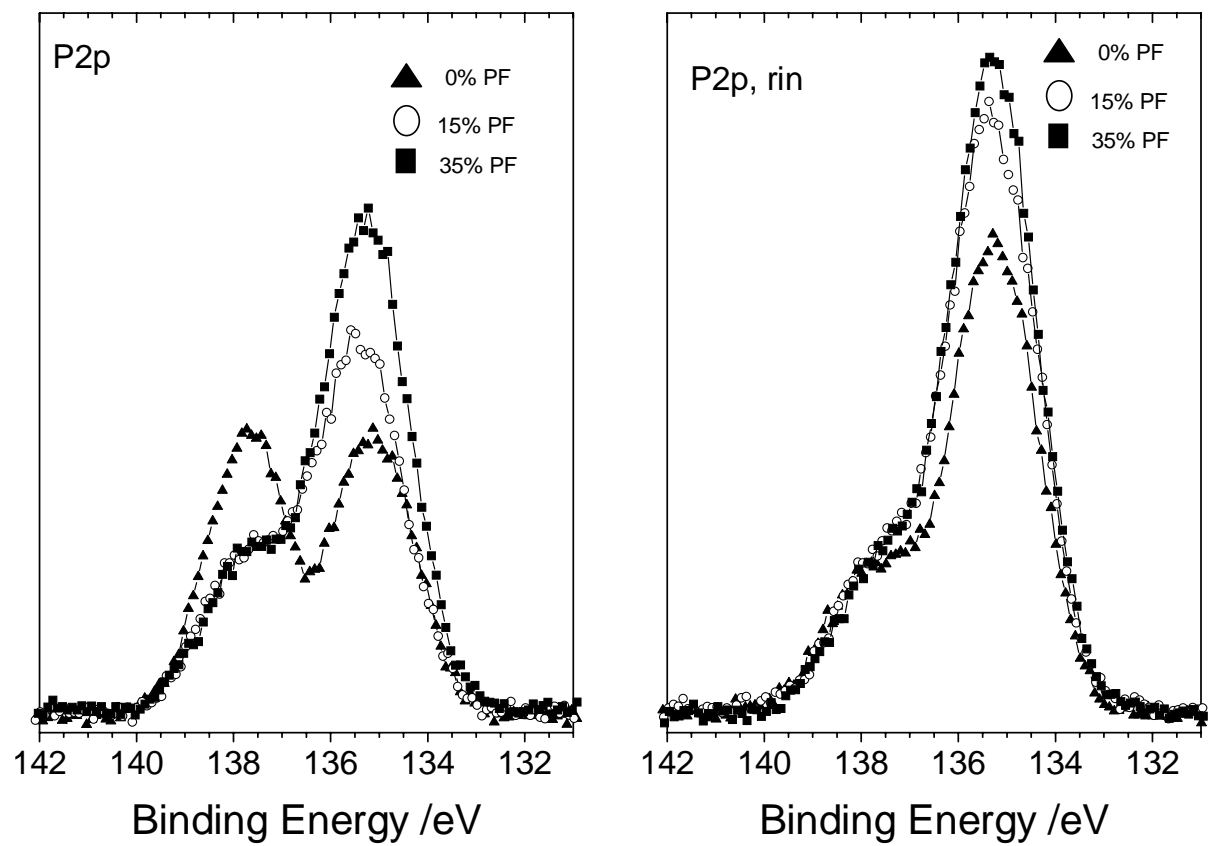
Fig. 7. (a) Li1s spectra from as disassembled $0 \%, 15 \%$ and $35 \%$ PF samples. (b) Comparing Li1s spectra from rinsed 0\%, 15\% and 35\% PF samples. Spectra are shown on same intensity scale.
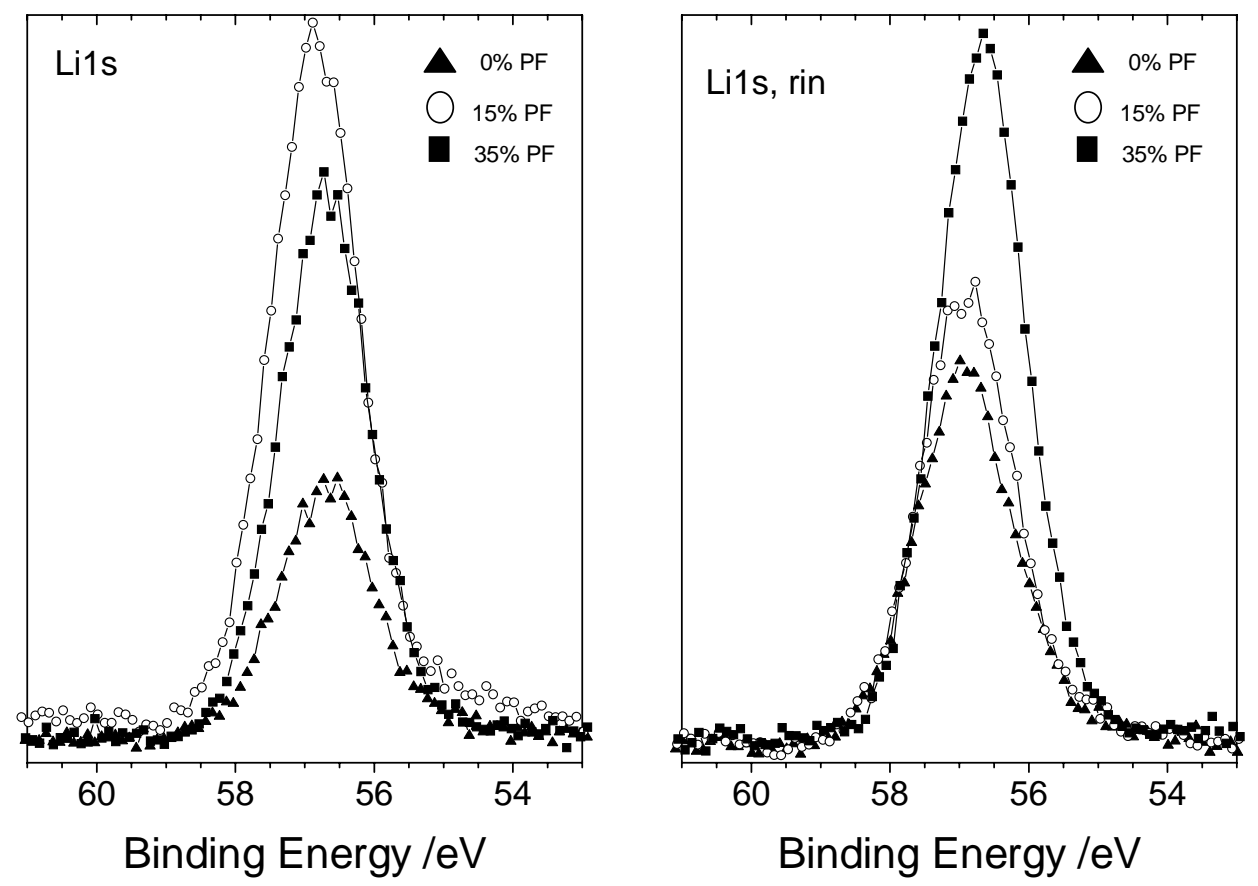
Fig. 8. C1s spectra prior to and after 60s sputtering (a) 0\% PF and (b) 35\% PF electrodes. Spectra are shown on same intensity scale.
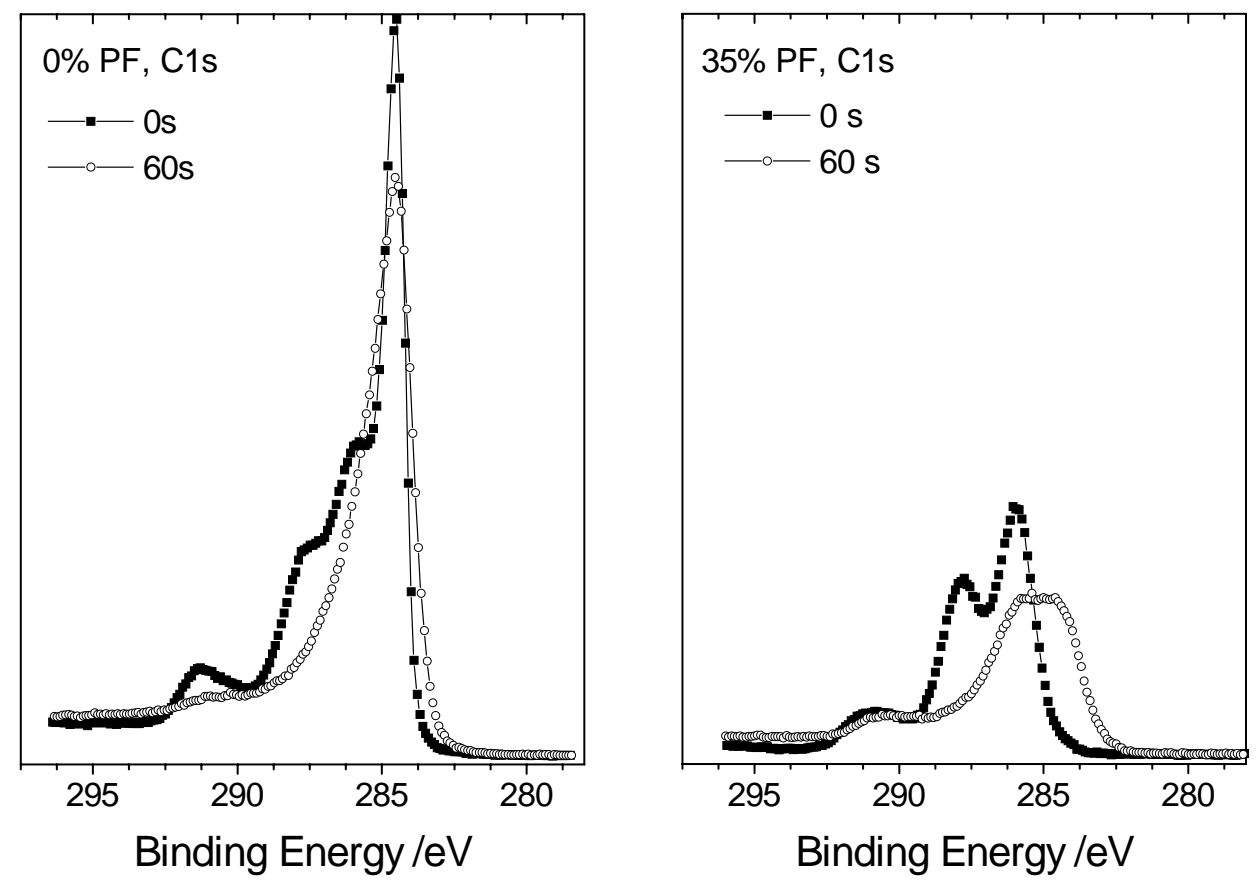
Fig. 8. O1s spectra prior to and after 60s sputtering (c) 0\% PF and (d) $35 \%$ PF electrodes. Spectra are shown on same intensity scale.
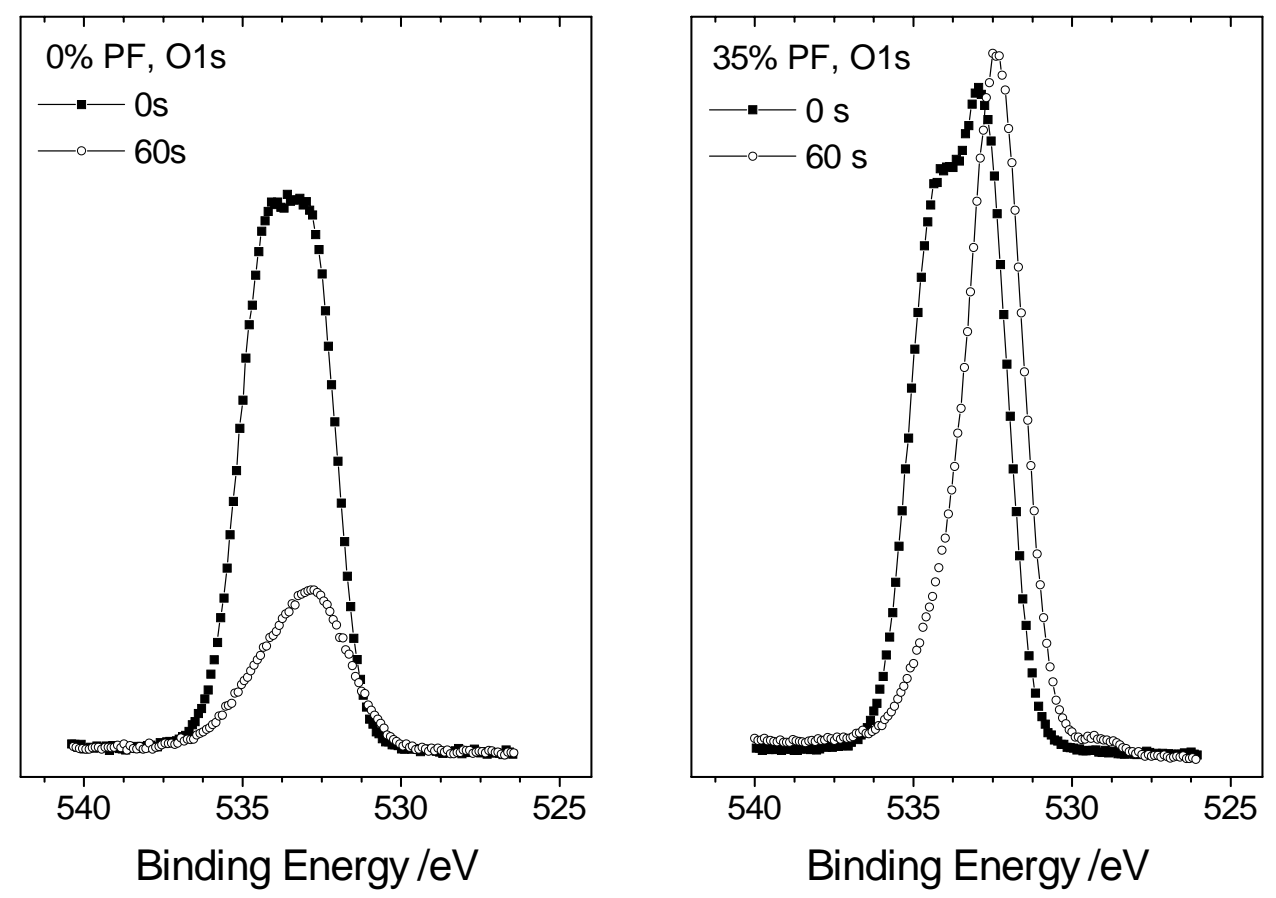
Fig. 8. F1s spectra prior to and after 60 s sputtering (e) 0\% PF and (f) $35 \%$ PF electrodes. Spectra are shown on same intensity scale.
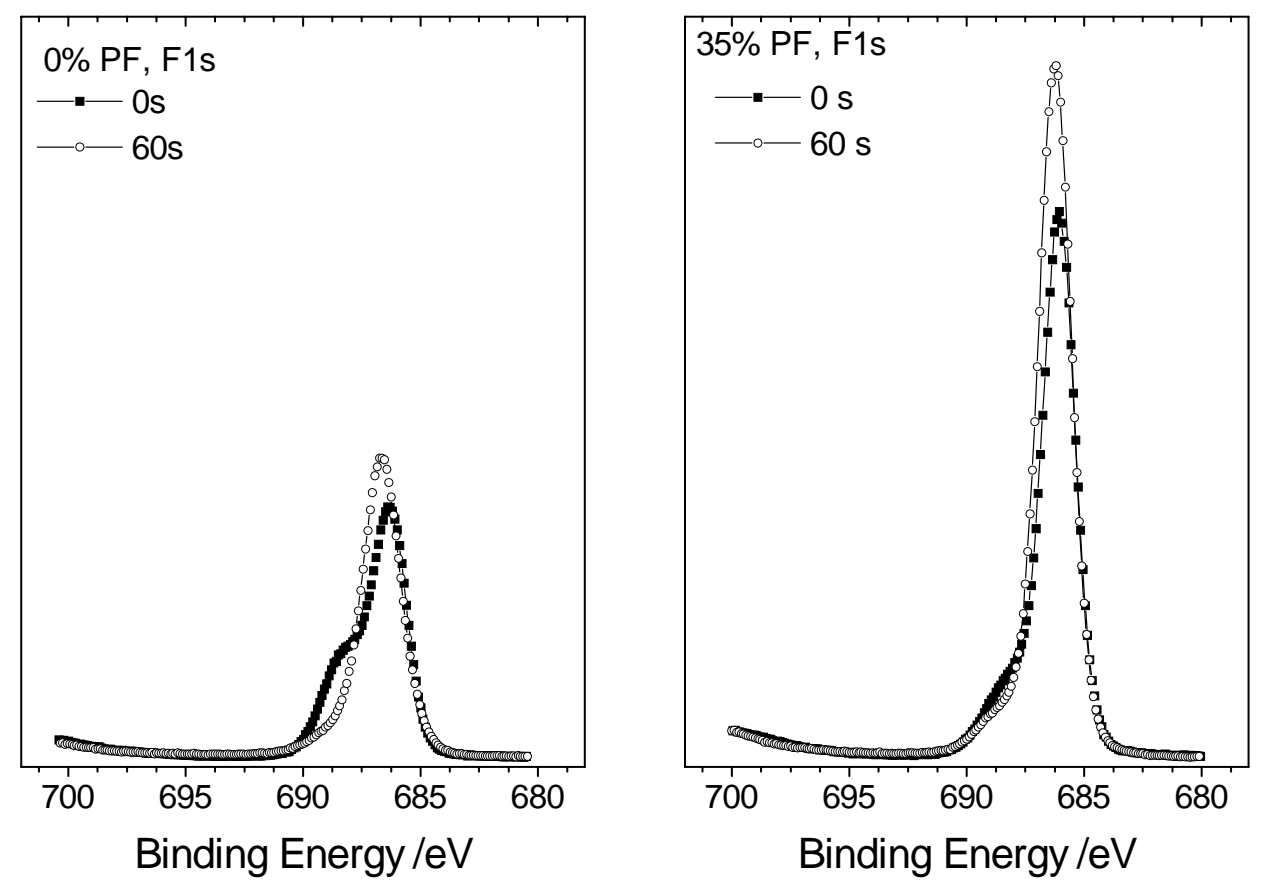
Fig. 8. P2p spectra prior to and after 60s sputtering (g) 0\% PF and (h) 35\% PF electrodes. Spectra are shown on same intensity scale.
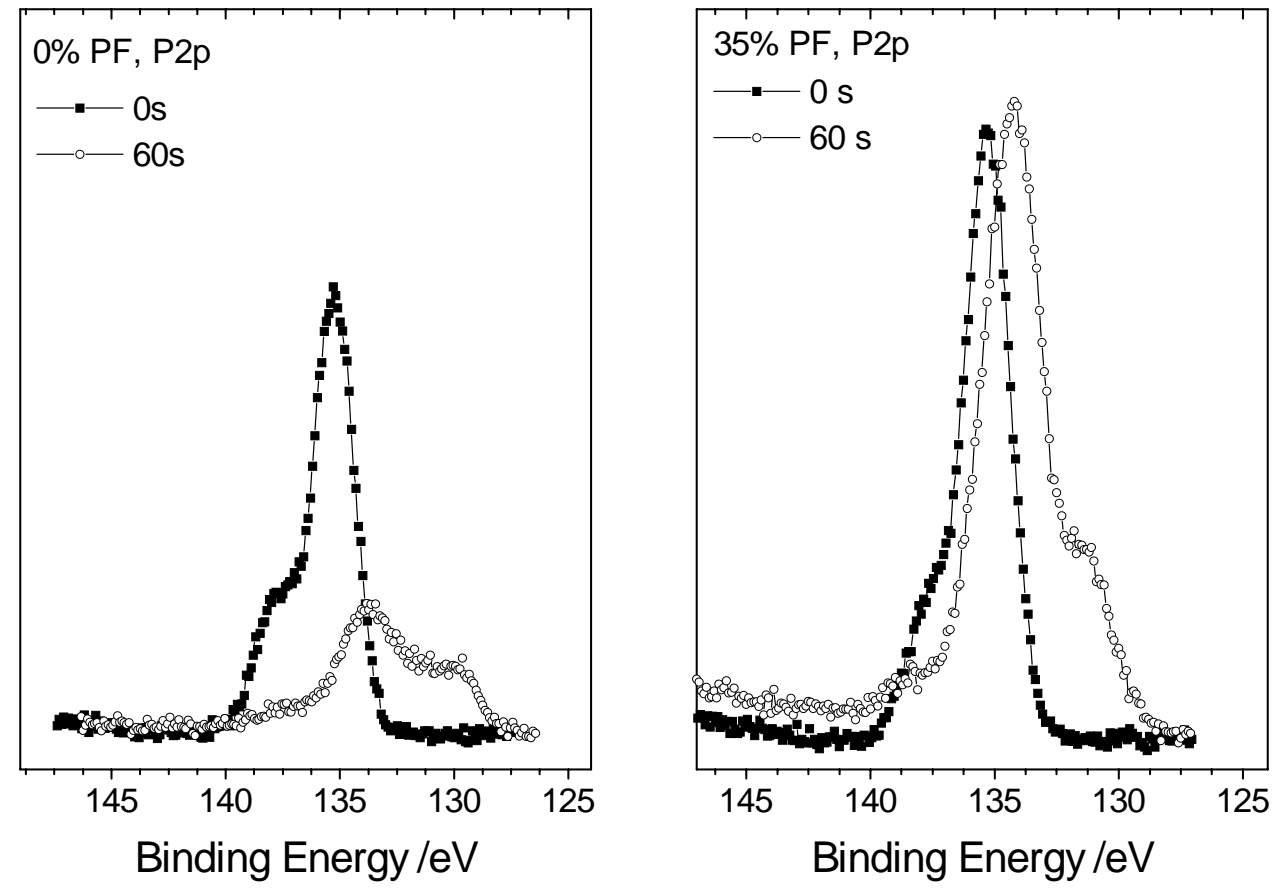
Fig. 8. Li1s spectra prior to and after 60s sputtering (i) $0 \%$ PF and (j) $35 \%$ PF electrode. Spectra are shown on same intensity scale.
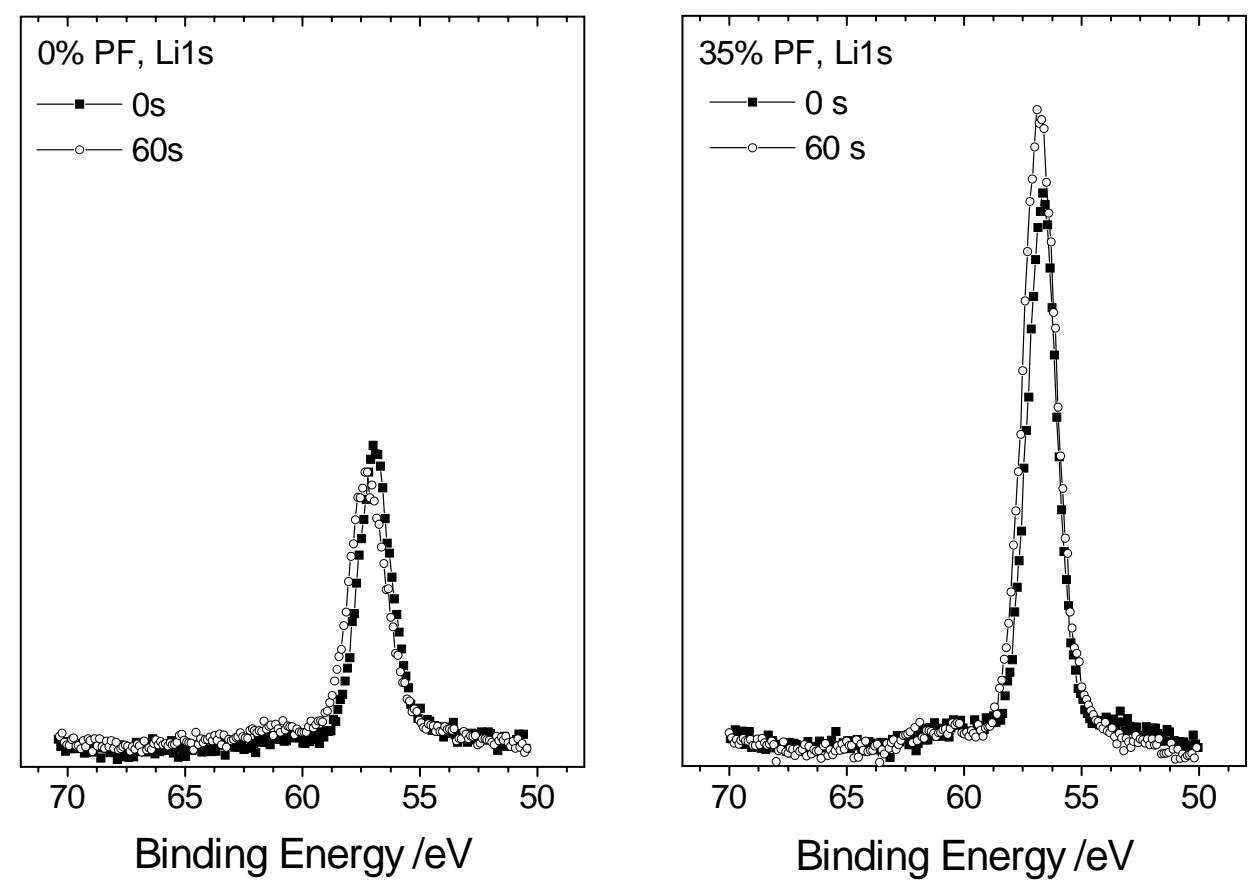
Fig. 9. Relative atomic concentration for (a) rinsed 0\% PF and (b) rinsed 35\% PF electrodes prior to and after sputtering for $20 \mathrm{~s}, 60 \mathrm{~s}, 120 \mathrm{~s}$, and $240 \mathrm{~s}$.
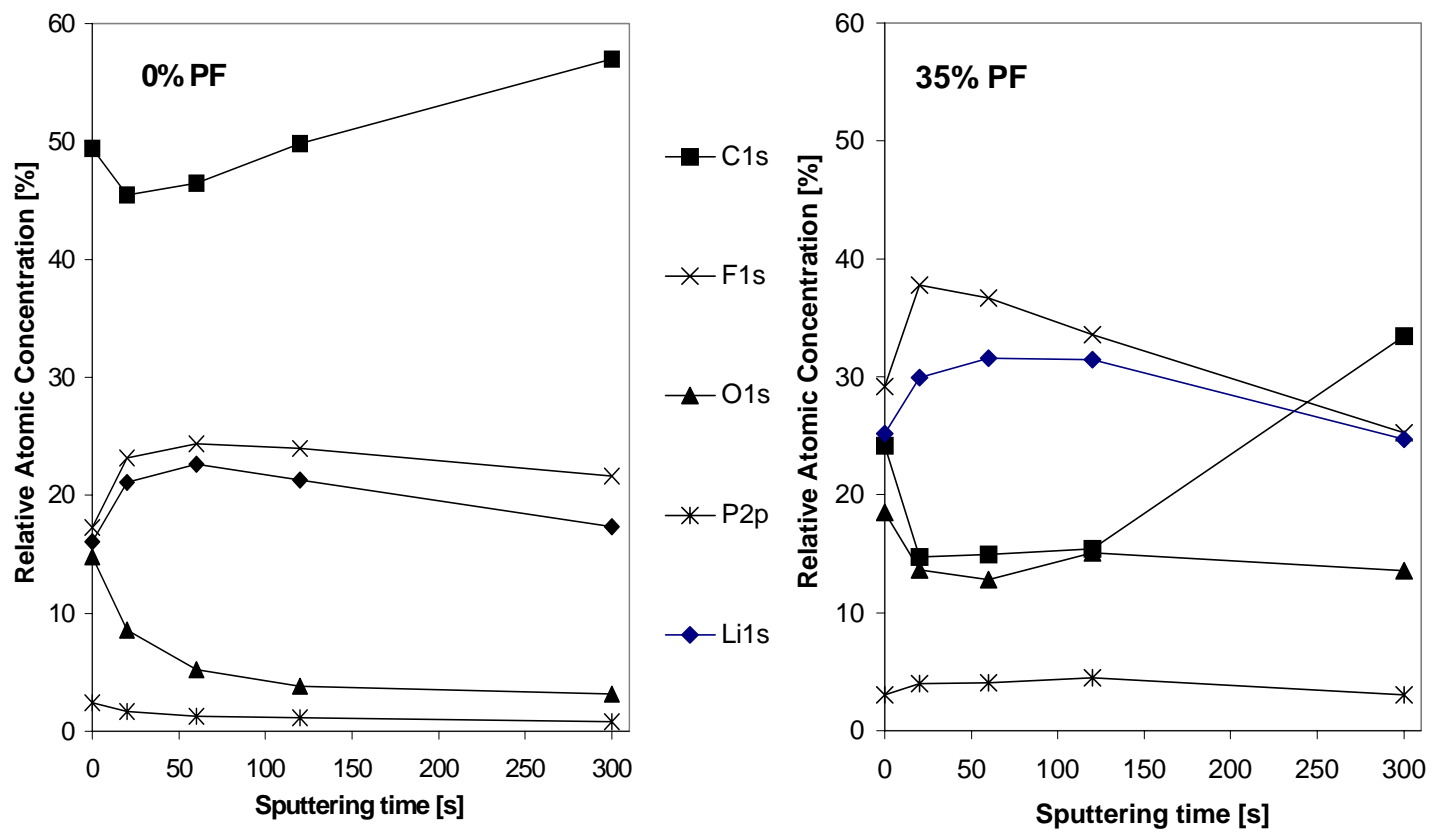
Fig. 10. (a) C1s spectra of $0 \%$ PF electrodes as disassembled and after air exposure for 3.5h. (b) C1s spectra of 35\% PF electrodes as disassembled and after air exposure for 3.5h. Spectra are shown on same intensity scale.
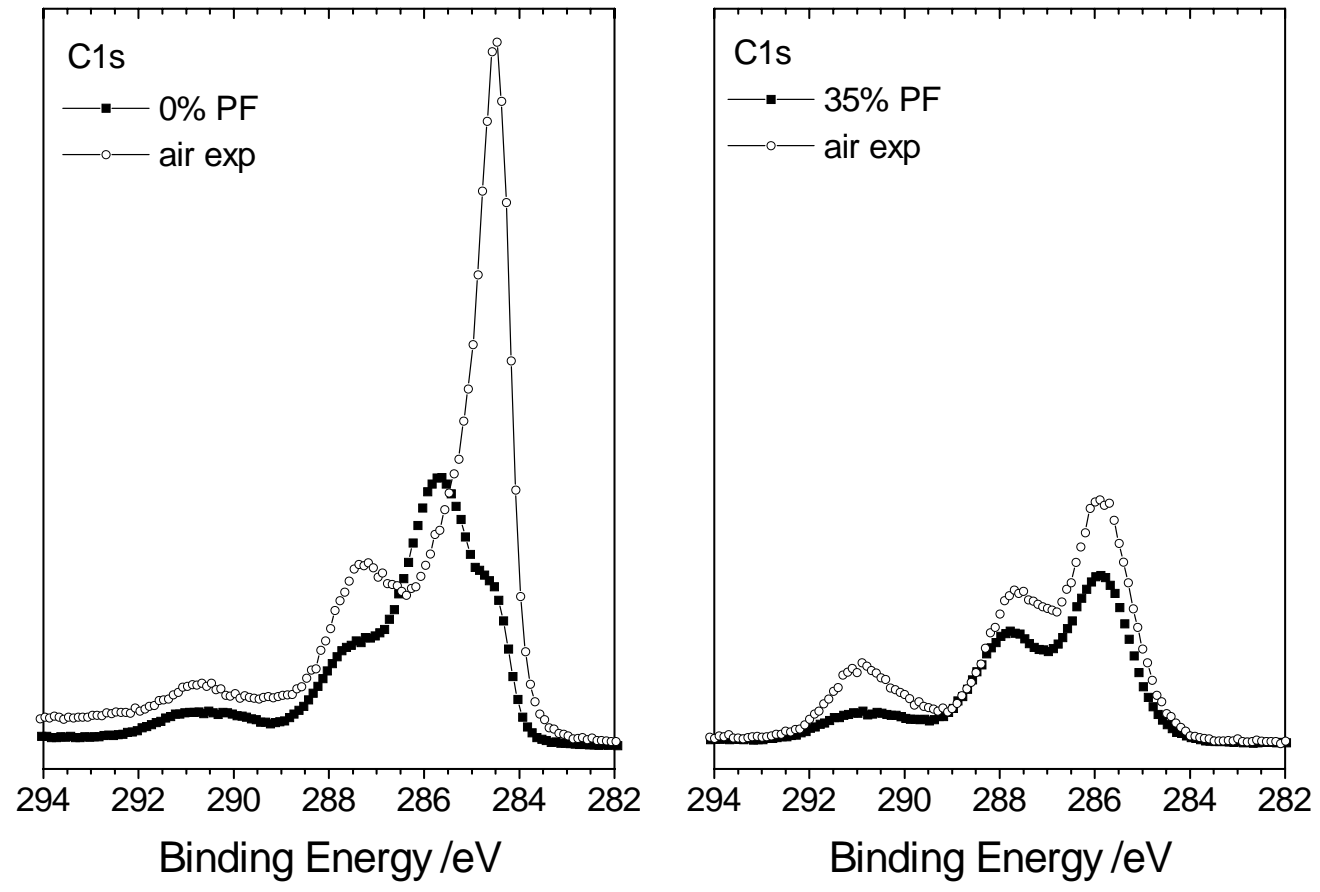
Fig. 10. (c) O1s spectra of 0\% PF electrodes as disassembled and after air exposure for $3.5 \mathrm{~h}$. (d) O1s spectra of 35\% PF electrodes as disassembled and after air exposure for $3.5 \mathrm{~h}$. Spectra are shown on same intensity scale.
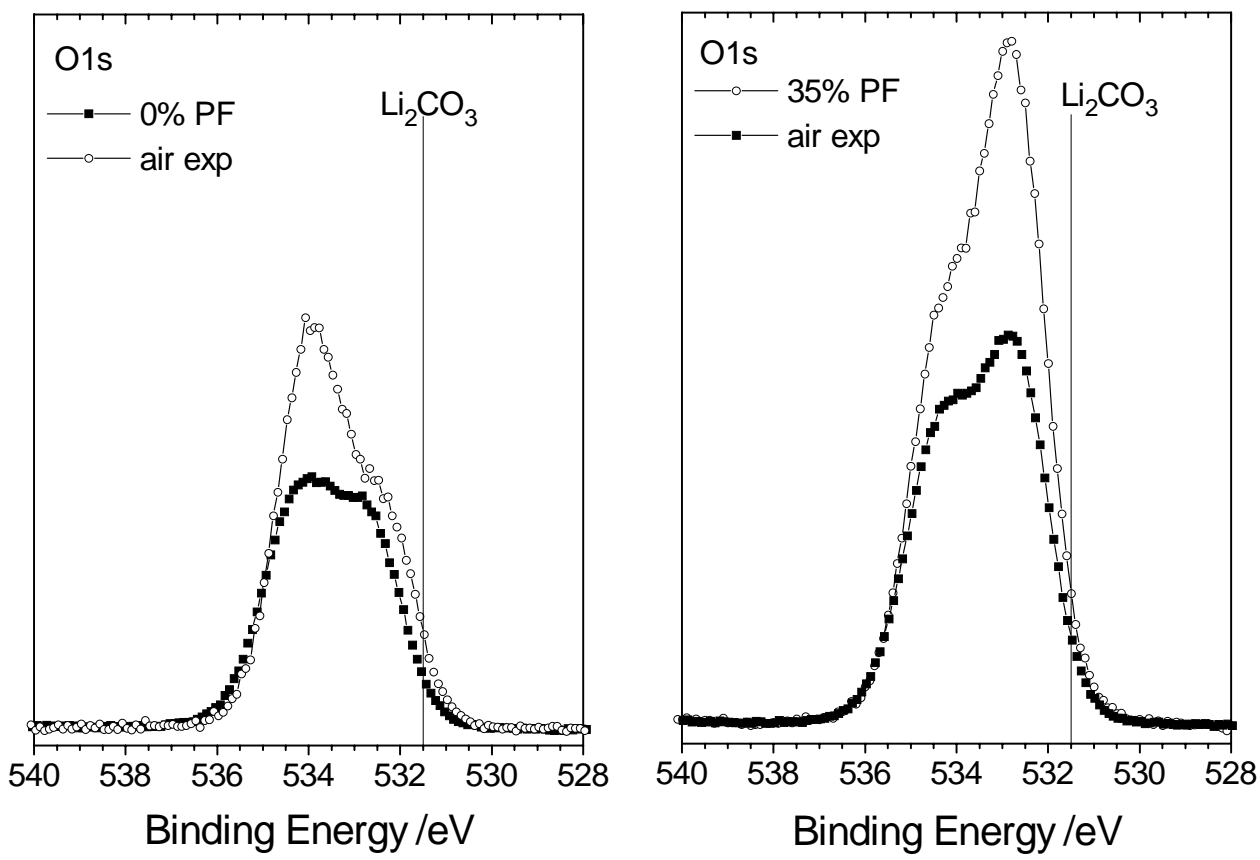
Fig. 10. (e) F1s spectra of $0 \%$ PF electrodes as disassembled and after air exposure for 3.5h. (f) F1s spectra of 35\% PF electrodes as disassembled and after air exposure for 3.5h. Spectra are shown on same intensity scale.
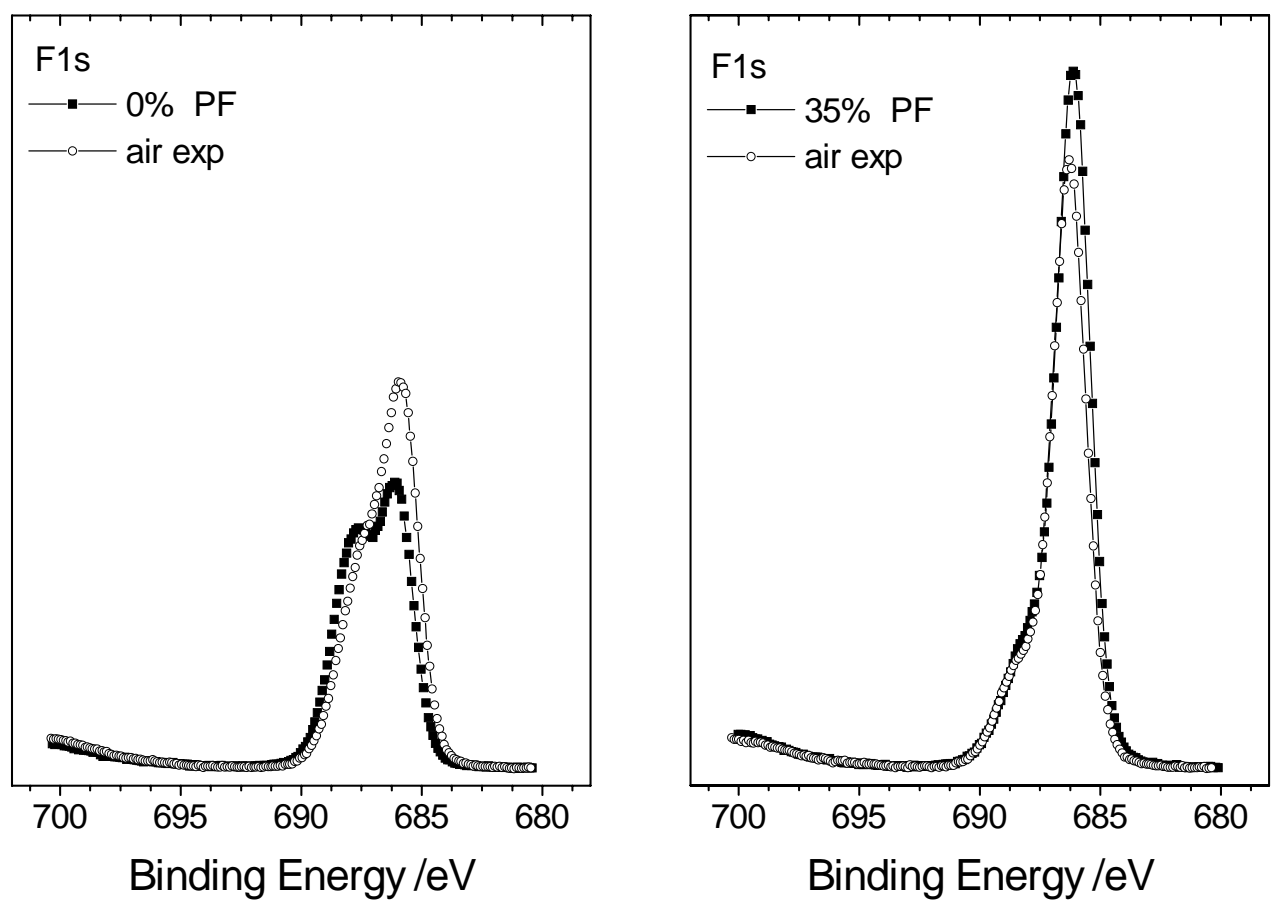
Fig. 10. (g) P2p spectra of $0 \%$ PF electrodes as disassembled and after air exposure for 3.5h. (g) P2p spectra of 35\% PF electrodes as disassembled and after air exposure for 3.5h. Spectra are shown on same intensity scale.
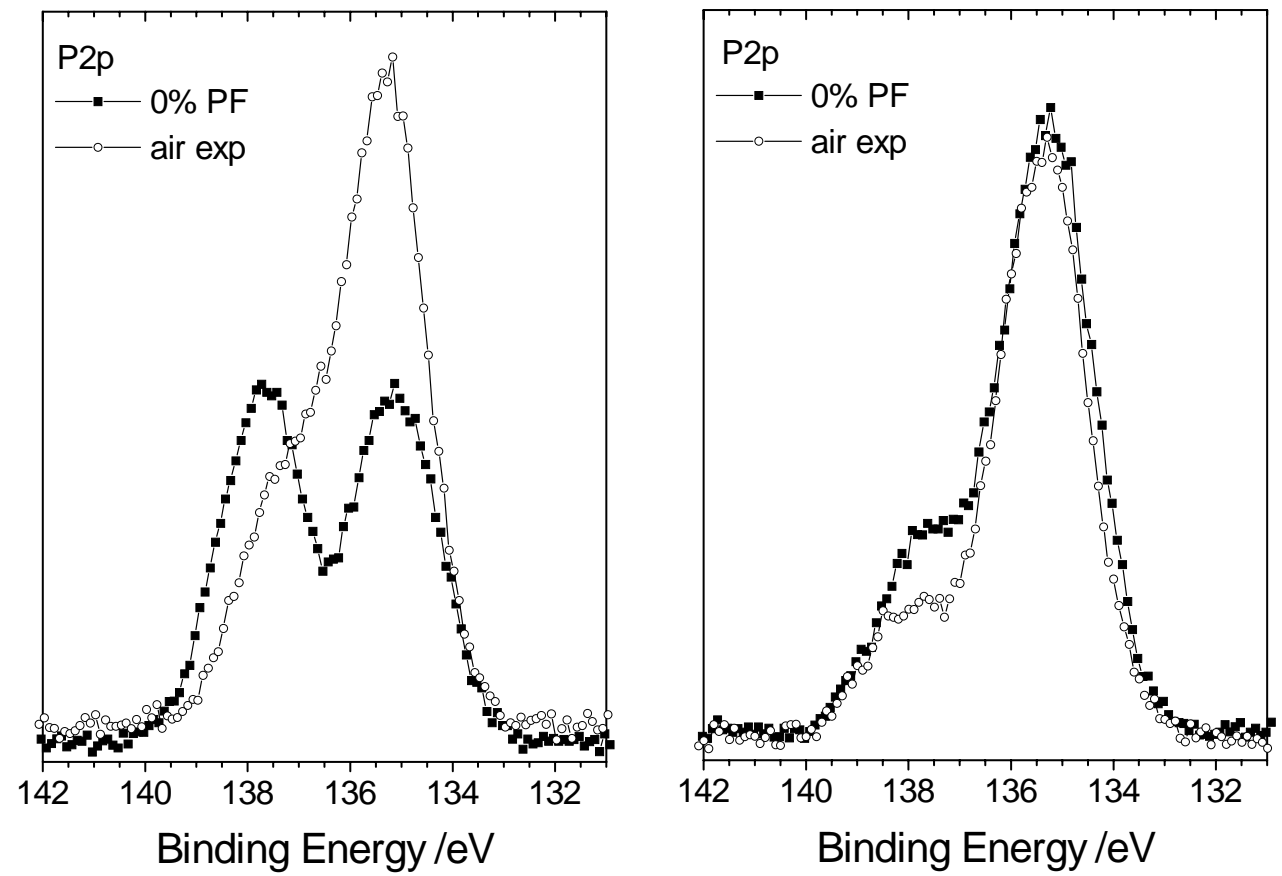
Fig. 10. (i) Li1s spectra of $0 \%$ PF electrodes as disassembled and after air exposure for 3.5h. (j) Li1s spectra of 35\% PF electrodes as disassembled and after air exposure for 3.5h. Spectra are shown on same intensity scale.
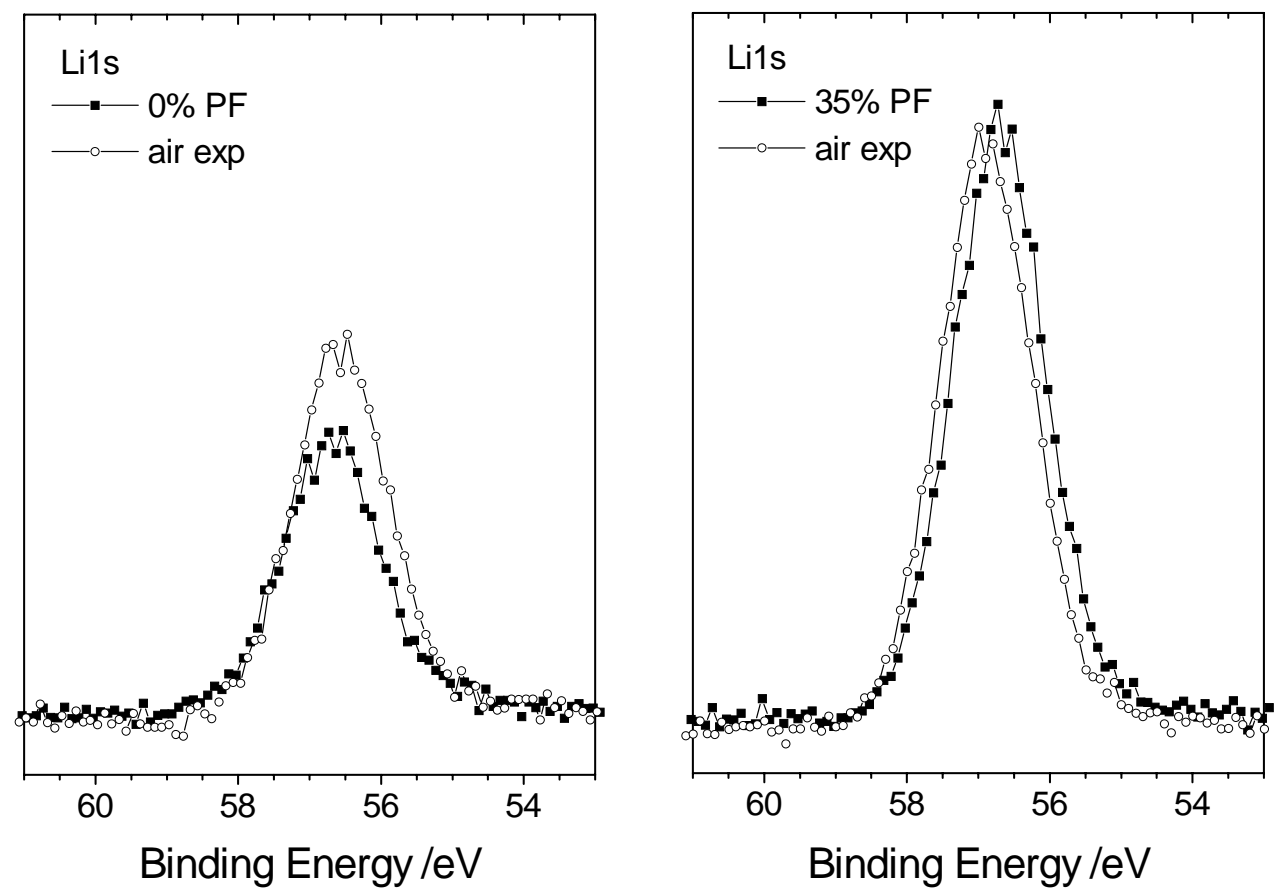
Fig. 11. Schematic showing the formation of alkyl-carboxylate (A) by EC reduction followed by reaction with $\mathrm{CO}_{2}$. An alkoxide (B) can result from the loss of $\mathrm{CO}_{2}$ from the carboxylate as shown.

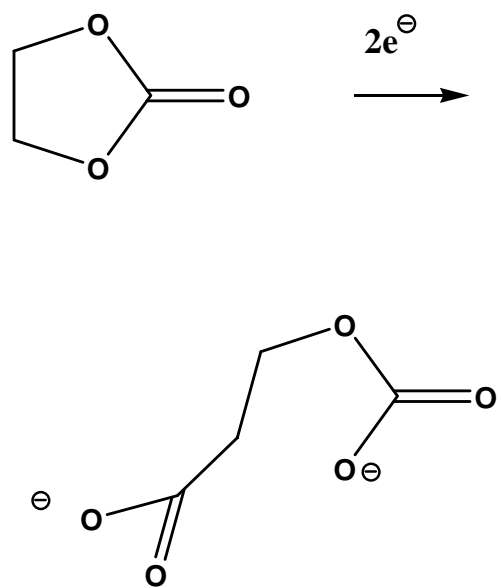

A

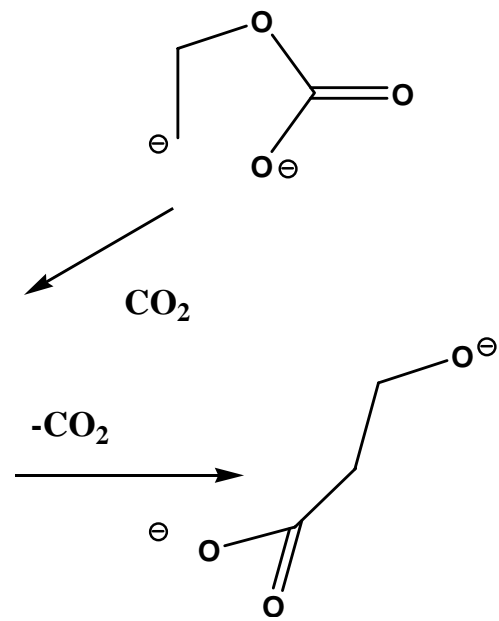

B 